\title{
Feeding mechanisms and ecology of pycnodont fishes (Neopterygii, $\nmid$ Pycnodontiformes)
}

\author{
Jürgen Kriwet ${ }^{1}$
}

With 16 figures and 1 tablc

\begin{abstract}
The functional morphology of the jaw apparatus and the skull and the feeding habits of the extinct pycnodont fishes are reconstructed in comparison with some extant halecostomes. For this, a short review of the functional units of the pycnodont head is given. The feeding mechanisms of pycnodonts exhibit a transition from simple stereotypic feeding kinematics. which are characteristic for primitive actinopterygians, to the modulating feeding kinematics of advanced teleosts and is called limited modulating feeding kinematics herein. Two structural specialisations which are found in halecostomes (operculum with distinct $m$. levator operculare and the interopercular bone with the interopercular ligament) are supposed to be absent in pycnodonts, whereas they maintain the two primitive couplings for direct mandibular depression (epaxial muscles - neurocranium, hypaxial muscles - cleithrum-m. sternohyoideus - hyoid apparatus). Advanced pycnodonts developed a new structure (upper jaw protrusion resulting in an enlargment of the buccopharyngeal cavity), that is absent in halecomorphs (e.g., Amia calva) and basal pycnodonts (e.g., $\nmid$ Arduafrons, $\dagger$ Mesturus). The premaxillae and maxillae are firmly fixed in basal pycnodonts, whereas the premaxillac and maxillae are free and movable in advanced pycnodonts. Pycnodonts were benthic foragers with a combination of biting or nipping and suction feeding based on the "truncated cone morphology" of the buccopharyngeal cavity. It is concluded, that pycnodonts certainly were omnivorous feeders with a general broad range of prey. But thcy were also a highly specialised group on generic level in respect to their prey. This is indicated by gut contents, as far as thev are known, which comprise only monospecific remains of shelled invertebrates (e.g., spines of echinoderms, shells of bivalves). The ecological demands of pycnodonts are discussed.
\end{abstract}

Key words: Neopterygii, Pycnodontiformes, fecding, gut contents, ecology.

\section{Zusammenfassung}

Die funktionelle Anatomie des Nahrungsaufnahmeapparates sowie das Fressverhalten der seit dem Eozän ausgestorbenen Neopterygier-Gruppe der Pycnodontier wird im Vergleich zu einigen rezenten Halecostomen (Amia calva, verschiedene Teleosteer) untersucht und diskutiert. Dazu wird cine kurze Übersicht über die funktioncllen Einheiten des Pycnodontierschädels gegeben. Die Kincmatik des Nahrungsaufnahmeapparates der Pycnodontier stellt einen Übergang von der einfachen, stereotypischen Kinematik primitiver Actinopterygier zu der modulierenden Kinematik fortschrittlicher Teleosteer dar und wird hier als limitierte, modulierende Kinematik bezeichnet. Zwei structurelle Spezialisationen, die bei Halecostomi entwickelt sind (Operculum mit distinkten $\mathrm{m}$. levator operculare und das Interoperculare mit dem interoperculare Ligament) fehlen bei Pycnodontiern, wogegen sie die zwei primitiven Verbindungen zwischen den epaxialen Muskeln und dem Neurocranium und zwischen den hypaxialen Muskeln, dem Cleithrum und dem Sternohyoidmuskel für die direkte Unterkieferabsenkung beibehalten. Fortschrittliche Pycnodontier entwickeln aber eine neue Struktur (bewegliches Maxillare und Premaxillare zur Erweiterung des buccopharyngealen Raumes), die bei Halecomorphen als auch ursprünglichen Pycnodontiern (z. B. $\dagger$ Arductfrons, $\nmid$ Mesturus) fehlt: Maxillare und Prämaxillare werden aus dem Schädelverband gelöst und beide werden gegeneinander beweglich. Während der Mandibulardepression schwingt das nun freie Maxillare um einen vorderen Artikulationszapfen antero-ventrad und drückt das Prämaxillare nach vorne in Richtung Beute. Die ökomorphologische Untersuchung zeigt, dass der Rachenraum als ,.truncated-cone", wie er für Teleosteer mit ausgeprägtem Schnappsaugmechanismus typisch ist, rekonstruiert werden kann. Die Kinematik des Kieferapparates der Pycnodontier repräsentiert somit eine Kombination aus reinem Beißen und Schnappsaugen. Pycnodontier ernährten sich vermutlich omnivor sowohl von schalentragenden als auch schalenlosen Invertebraten ernährten. Vermutlich waren die einzelnen Gattungen aber hochspezialisierte Beutegreifer. Dies lässt sich mithilfe der überlieferten Mageninhalte zeigen, die monospezifisch für jede Gattung sind.

Schlüsselwörter: Neopterygii, Pycnodontiformes. Fressverhalten, Mageninhalte, Ökologie.

I Institut für Paläontologie, Museum für Naturkunde, Zentralinstitut der Humboldt-Universität zu Berlin, Invalidenstraß3e 43, D-10115 Berlin, Germany.

Received February 2001, accepted July 2001 


\section{Introduction}

The jaws and heir associated elements of fishes are used in many ways to capture. process. transport, and swallow food (e.g.. Gillis \& Lauder 1995). The structure of the dentition and composition of the diet of modern actinopterygians have been wicely used to infer the nutrition of fossil actinopterygians and to make assumptions on ecological temands. It is accepted. that the study of funciional morphology enables us to better understind selective forces in the evolution of organisms (Osse 1969. Lauder 1990. 1995). The functional morphology of the feeding apparatus and its kinematics must be carefully examined to understand the processes of food capture and its processing correctly. Nevertheless, only obse vations, which are not possible in fossils, could give reliable results. Stomach contents could prove or disprove the deduced functional and eco ogical demands. This is a difficult task in fossils. because the preservation of stomach contents is not the rule. The literature on feeding habits including the functional morphology of the sku 1 and feeding apparatus in combination with a study of stomach contents in extant and fossil actinopterygians is extremely sparse. Nevertheless, the biomechanical fragmentation of shells by certain extant actinopterygians and its importance have been described by several authors (e.g. Boucot 1981. Trewin \& Welsh 1976. Cate \& Evans 1994). Those results have been rarely use $d$ to interpret fossil shell damages and accumulations (e.g.. Robba \& Ostrinelli 1975, Tintori 1'995).

The feeding habits of extant actinopterygians have been stucied by many authors since the beginning of the $20^{\text {th }}$ century (e.g., many papers by K. F. Liem and G. V. Lauder). They showed. that the cranicl musculo-skeletal system of actinopterygians is an extremely complex multilinkage system wit 1 more than 30 movable bony elements controlled by more than 50 muscles in Recent teleost: (Lauder 1983). Most authors imply, that function and structure of skeletal complexes are clos sly related as no part works alone but interacts with other components (e.g.. Dullemeijer 1974, Thomas 1978). Hence, the understanding of the relationships between function and structure would explain complex and dynamic processes like feeding and respiratory mechanisms. The study of functional anatomy of the head of extant actinopterygians involves several closely related topics: the cranial osteology. myology (the description of muscles between functional units), ligaments and arthrology, and motion analysis based on electromyography and high speed motion pictures of prey capture and respiratory. This enumeration of approaches, which are all commonly used in living forms, elucidates the problems one deals with in palaeontology. The inability to study soft tissues and related kinematics in fossils is the reason, why the inference of function from structure alone is widely used in palaeontology, although the extrapolation of function from form may only give limited knowledge of the real functions. The head of actinopterygians is generally divided into several functional units ("intimately associated aggregations of bony elements, ligaments, and muscles performing in a close union") of one or more functions for studying its functional anatomy (e.g.. Liem 1967, Osse 1969). This definition confirms the problems in palaeontology again, because the reconstruction of soft tissues is rather speculative in most cases.

Generally, five methods for studying the functional morphology in modern fishes are used. Some of these methods have been applied to functional morphology in fossils. (1) The phylogenetic method relies on the phylogenetic relationships of organisms; relationships between structure and function found in Recent taxa are applied to extinct relatives (e.g., Stanley 1970, Raupp \& Stanley 1971). (2) The paradigm method It was first introduced by Rudwick (1964) and subsequently discussed in the palaeontological literature (e.g., Gould 1970, Raupp \& Stanley 1971. Grant 1972, Cowen 1979, Hickman 1988). Here, function is inferred from structure by developing and proposing several mechanical abstractions or models. These models are then used to predict, what a structure should look like. This method may be considered as a variant of the general approach of making mechanical or mathematical models to deduce structures, that might perform the functions included in the model (Dullemeijer 1974, Gutmann 1981, Lauder 1995 discussed the phylogenetic (1) and paradigm (2) methods and their difficulties to some extent.). (3) The ecomorphological paradigm (e.g.. Clements \& Bellwood 1988, Liem 1993). This paradigm accepts, that the morphology of the skull relates to how the animal feeds. Variations observed in the skull anatomy are thus correlated with inter- or intraspecific differences in diet. (4) High-speed cinematography in combination with recording of the electrical activity pattern of muscles (e.g., Liem 1970, Lauder 1995). This combined methods is only possible in 
extant forms. Lauder (1995) presented a case study concerning the feeding habits of extant osteoglossomorphs based on the electrical activity pattern of muscles. The results show, that there exists considerable discordance between structure and function in the musculo-skeletal system. The key reason for this is the nervous system. Minor changes of the central nervous structure and function have the capability of extremely changing the accuracy of predictions based on musculo-skeletal morphology alone (Lauder 1990, 1991, 1995). The results are in fact very pessimistic for palaeontologists, because they imply, that it is impossible to reconstruct the functional morphology alone from the bony parts of an organism. (5) The importance of soft tissues in the study of the functional morphology of fossil taxa was also discussed by Witmer (1995). Generally, the reconstruction of soft tissues in fossils is based on comparison with extant relatives. Consequently, Witmer (1995) introduced the extant phylogenetic bracket approach (EPB). This method resembles the phylogenetic method described above.

Recently, Westneat (1999) reinforced the value of biomechanical principles and mechanical models of the musculo-skeletal system derived from living taxa for the study of the functional morphology of fossils. The models used by him are based on sets of morphometric variables, that have direct functional relevance to force and velocity characteristics of actinopterygian jaws.

Pycnodonts are generally regarded as shellcrushers. Their ecology and feeding habits were described in general terms by Nursall (1996a). He proposed, that pycnodonts inhabited shallow marginal, often reefal seas and were restricted to durophagous habit. In contrats to this, PoyatoAriza et al. (1998) suggested, that pycnodonts were also adapted to fresh-waters. I will present new results and discuss herein the feeding habits of the extinct pycnodont fishes, which are interpreted as a monophyletic group and as sister to all other neopterygians (Kriwet 2001). Thus, the kinematics of the feeding apparatus are studied by briefly analysing the morphology of the skull including the bony structures as well as presumed soft tissues in comparison with extant halecomorphs (e.g., Amia) and teleosts (e.g., Anarrhichas, Lamprolagus, Scarus). Linkage models are developed in comparison to those established by Lauder (1982) to show the interactions of the skeletal and proposed soft tissues during feeding. The development of mechanical models provides for the first time a broad conceptual framework for interpreting the functional morphology of pycnodont feeding. In addition, preserved gut contents are considered to reconstruct their feeding ecology.

\section{Material and Methods}

Pycnodont material: Remains of pycnodont fishes are abundant in Mesozoic and Palaeogene deposits world-wide. Therefore, most museums have a lot of pycnodont material. In the last few years, more than 1000 specimens belonging to about 145 species of pycnodonts have been studied (Kriwet 2001). This material is housed in 32 institutional collections all over Europe and the U.S.A. Most material, which forms the basis of this study, consists of more or less articulated specimens from the Late Triassic, Early to Late Jurassic. Late Cretaceous, and Eocene. In addition, isolated dentitions and disarticulated skulls were used to study the joints of the jaw elements and the abrasion patterns on teeth. Some isolated elements (e.g., vomers, prearticulars, teeth) and an isolated skull were studied in transversal ground section. Several specimens were prepared using acetic acid, but most material was already mechanically prepared. Drawings were prepared under Wild M5 and M8 microscopes. Photographs were prepared by the author and W. Harre (Berlin). A complete list of the investigated material is presented in Kriwet (2001). and it is not useful to repeat it herein.

Myology, ligaments, and arthrology: The knowledge of the myology, the arrangement of ligaments, and the joints or couplings between bony structures are important to understand the kinematics during feeding. Unfortunately, the reconstruction of soft tissues in exclusively fossil known taxa is speculative. Nevertheless, there are many osteological related features like tuberosities, crests, grooves, fenestrae, fossae, foramina, and septa and the absence of certain bones (e.g., interoperculum, urohyal), that allow some assertions about soft tissue anatomy. In addition, the soft tissues and the arrangement of muscles and ligaments in the skull of extant sparids, acanthurids, nandids, and Anarrhichas lupus, which are assumed to be similar to pycnodonts in their dentition and to some extent also in their skull-shape and the extant Amia have been studied for comparison based on literature data (e.g., Lubosch 1929, Dobben 1937. Willem 1942. 1944, 1945, 1947, Osse 1969, Liem 1970, Winterbottom 1974. Bellwood 1994) and by personal observations. The study of ligaments is extremely important in functional analysis of the feeding apparatus, because ligaments determine the direction, degree, and speed of motions between the bony clements (Liem 1970). Mobile joints between the functional units and within the units are important in understanding functional anatomy and analysing the motion of these units. The articulations between functional units found in Recent teleosts and Amia were described by Alexander (1967a. b. 1970), Liem (1970), Lauder (1979, 1982), and Jollie (1984). The data are summarised in Kriwet (2001).

Feeding in halecomorphs and teleosts: The evolution of different feeding strategies and kinematics of actinop terygians is related to changes in the structural and functional network of the skull. Most functional studies of the feeding habits of actinopterygians are focused on extant teleosts so far. Data of the head morphology and the feeding kinematics of the extant halecomorph Amia and fossil and extant teleosts are taken from Arratia $(1997,1999)$, Alexander (1967a, b), Gosline (1965), Lauder (1979, 1980a, 1982). Liem (1970), Patterson (1973, 1977), Patterson \& Rosen (1977), and others. Additionally, the head morphology of extant sparids, roaches, and Anarrhichas were investigated. The structural network in the head of pycnodonts related to 
mouth opening ar d suction feeding is reconstructed as network following Lauder (1980a).

Institutional fabbreviations: Certain specimens cited in the text arc housed in the following institutions: AMNH. Department of $V_{t}$ rtebrate Paleontologr. American Museum of Natural Hisıry. New York: BGMM. Bürgermeister Müller Museum. Solnhofen: BMNH. The Natural History Museum. London: B؟P. Bayerische Staatssammlung für Paläiontologie und historische Geologie. München: MB. Museum für Naturkunde. Berliu: MGSB. Museo Geológico del Seminario. Barcelona: MNHI. Museum national d'Histoire naturelle. Paris: and VFKC. Verein der Freunde und Förderer des Naturkundemuseu ns Ostbavern e.V.

\section{Cranial skeleton}

The cranial skeleton of pycnodonts is only summarised hereir. Functional units of the pycno- dont skull are the dermatocranium, the endocranium including the parasphenoid and vomer, the suspensorium apparatus including hyomandibula, preoperculum. ectopterygoid, entopterygoid, and metapterygoid. symplectic, and quadrate, the opercular apparatus, the jaw apparatus, the hyoid apparatus, and the branchial apparatus. The pectoral girdle is also functionally important in depressing the mandible, because it is pulled anteriorly when the mandible is adducted. For interpretation of the pectoral girdle see Nursall (1996b, 1999a, b) and Kriwet (2001).

Cranium: The dermato- and endocranium of pycnodonts have been described by several authors (e.g.. Dunkle \& Hibbard 1946, Gayet 1984. Bell 1986. Lambers 1991, Nursall 1996b,
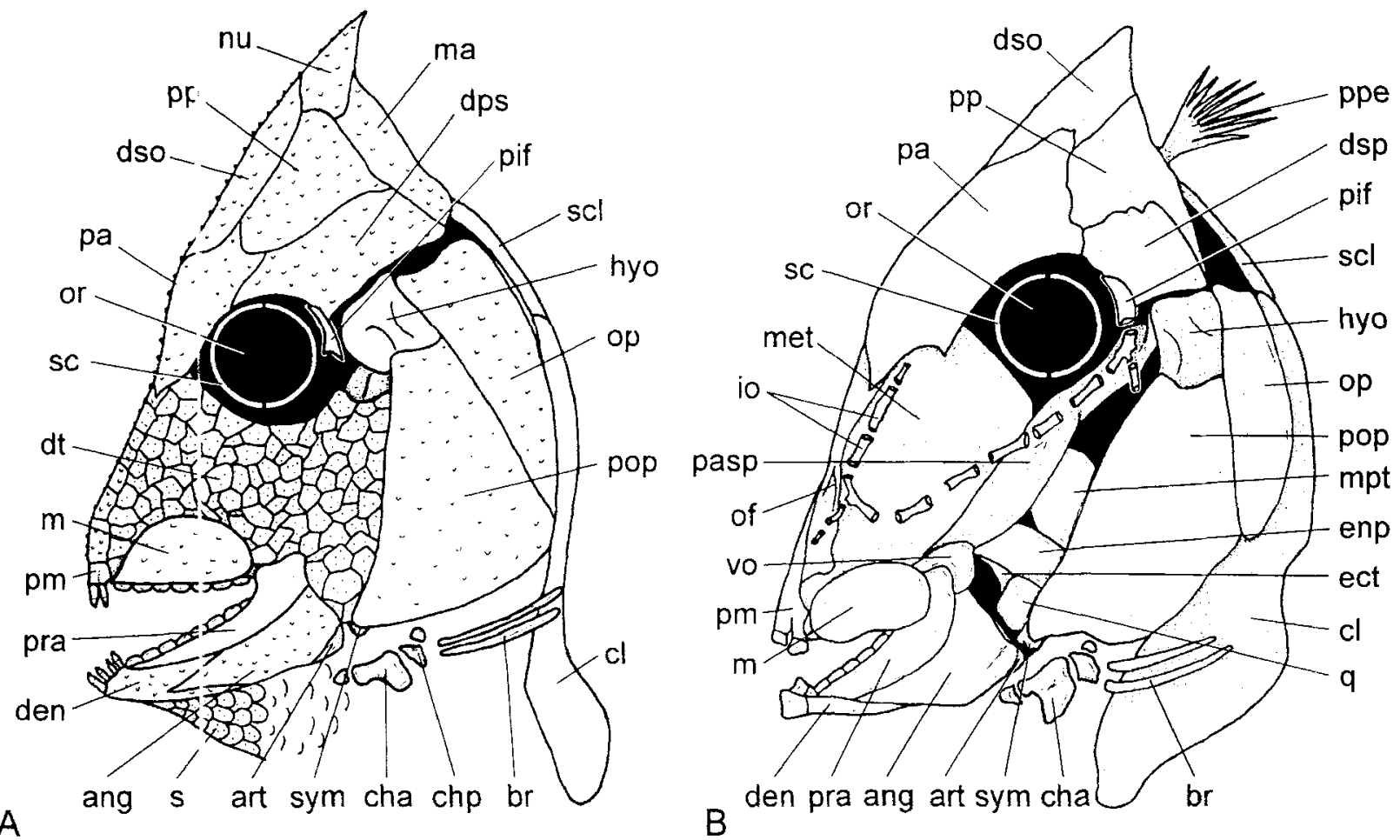

Fig. 1. Restoration of pycnodont heads in lateral view. A. †Grodus hexagomus. B. $\dagger$ Proscinetes elegans. Not to scale. ang. angular bone [- articular of Allis 1897 and dermarticular of Goodrich 1930]: art articular bone; br. branchiostegal rays; cha anterior cerat shyal I = ccratohyal of Bridge 1877. Allis 1897 and others: distal ceratohyal of Patterson 1973.]; chp. posterior ceratohyal [ = spihyal of Bridge 1877. Allis 1887a and others: proximal ceratohyal of Patterson 1973.]; cl, cleithrum [= clavicle of Allis 1837): den. dentalosplenial I= dentary of Grande \& Bemis 1998 and others. The dentary of actinopterygians might not be homologous with the dentary of sarcopterygians (Jarvik 1980). Jollie 1986) and the term dentalosplenial proposed by Jollic 1984. 1986 is retained): dps. dermopterosphenotic. following Kriwet et al. 1999 [= dermopterotic of Wenz 1989a, b, Nursall 1996b, 199') a. Compound bone consisting of portions of the dermopterotic and dermosphenotic]; dso, dermosupraoceipital. following $\mathrm{N}$ rsall 1996b. 1999a: dt. dermal tesserae: enp. endoptervgoid [= entopterygoid of Allis 1897, Nursall 1996b, and others: pteryg oid of Jollie 1984: mesoptervgoid of Bridge 1877]: ect. ectopterygoid; hyo. hyomandibula; io, infraorbital, tubular ossifications surrounding the infraorbital canal: $\mathbf{m}$. maxilla: ma. marginal skull bones $[=$ dermal elements at the posterior margin of the skull. The homology of these bones is unclear]: met. mesethmoid [= ethmoid]; mpt. metapterygoid; nu, nuchal scute [ = median extrascapular of Nursall 1999al: of olfactory fossa: or, orbit: op. operculum; pa, parictal bone [The dermal skull bone called frontal in actinopteryians by many authors. e.g. Jollie 1984a. Nursall 1996b. 1999a, and Grande \& Bcmis 1998 is not lomologous to the frontal of sarcopterygians. e.g. Schultze \& Arsenauld 1985. Arratia \& Cloutier 1996, but corresponds to the parietal of tetrapods.]: pasp. parasphenoid: pif. posterior infraorbital [dermosphenotic]: pm. premaxilla [= rhinopremaxillary if Jarvik 1980]: pop. preoperculum; pp. postparietal bone [The term postparietal is used here for actinoptervians following $S$ h hultze 1903 instead of the term parietal: see also pa.]: ppe. postparietal process [= postparietal peniculus of Nursall 1996b. 199 Ja]: pra. prearticular hone; q. quadrate: s. scale. sc. sclerotic ring elements; scl, supracleithrum; sym. symplectic: vo. vomer. 
1999a, b, Kriwet 1999a, 2001, Kriwet et al. 1999). The cranium of pycnodonts is considerably reduced in comparison to that of Ginglymodi, Halecomorphi, and teleosts. The standard pattern of the dermal skull of adults includes an unpaired dermosupraoccipital, paired postparietals, parietals, dermopterosphenotics (compound bones), and posterior infraorbitals (Fig. 1A, B). In contrast to other neopterygians, pycnodonts lack nasal, rostral, supra- and suborbital, supramaxilla, posttemporal, suboperculum, interoperculum, and gular bones. The endocranium of pycnodonts displays fewer ossified elements than that of other neopterygians (Kriwet 2001). The endocranium is badly preserved in most specimens, and only few elements seem to be consistent throughout the Pycnodontiformes. The generalised pattern includes a large median mesethmoid, unpaired supraotic and orbitopterosphenoid, and paired hyomandibulae, symplectics, quadrates, metapterygoids, exoccipitals, prootics, pterotics, sphenotics, and epioccipitals. Dermal elements of the endocranium are the paired ento- and ectopterygoids, and the unpaired parasphenoid and vomer. The braincase is covered dorsally by a median chondral bone, which is located within the otico-occipital region. This bone is rather large and consists of a slightly expanded base and a large ascending plate, which ends just beneath the dermal skull covering. Nursall (1996b) identified this bone as supraoccipital and interpreted it as a synapomorphy for pycnodonts. However, he assumed this bone also being a synapomorphy of pycnodonts and teleosts in the same paper. Maisey (1999) studied this bone in acid-prepared specimens of Neoproscinetes penalvai and concludes, that the supraoccipital bone of Nursall (1996b, 1999b) is actually the supraotic sensu Patterson (1975), because of its supposed position in front of the occipital fissure, its position above the anterior semicircular canals, and its fusion with the pterosphenoid. This assumption corresponds well to the phylogenetic hypotheses proposed by Arratia (1999) and Kriwet (2001), which show, that the supposed supraoccipital bone of pycnodonts is not homologous with that of Leptolepis coryphaenoides and more advanced teleosts.

Suspensorium apparatus: The preoperculum is included in the opercular series by most authors. But functionally, the preoperculum of actinopterygians belongs to the suspensorium apparatus, since it serves as the origin of the adductor mandibulae muscles. The suspensorium
(Fig. 1B) of pycnodonts is almost vertical, as it is in teleosts. It consists of: ectopterygoid, entopterygoid, metapterygoid, hyomandibula, quadrate, preoperculum, and symplectic.

The pterygoid bones are placed above each other, and this condition has been proposed as a synapomorphy for pycnodonts (Lambers 1991. Nursall 1996b, 1999b).

The quadrate is massive, situated ventrally to the entopterygoid, and abuts the symplectic (Fig. 2). In contrast to teleosts, the quadrate lacks the postero-ventral process. A quadratojugal is not present contrary to the assumptions made by Nursall \& Maisey (1991).

The form of the preoperculum differs among pycnodonts. It is rather triangular in some forms. where the upper part is only partly reduced (e.g.. $\dagger$ †ibbodon) to roughly rectangular in more advanced ones with largely reduced preoperculum (e.g., †Pycnodus, $\nmid$ Proscinetes: Fig. 1B). This reduction of the upper dermal part of the preoperculum is striking. The degree of reduction is not consistent within pycnodonts but varies from genus to genus. The preoperculum is strongly reduced in size in advanced pycnodonts (e.g., $\nmid P y c-$ nodus).

The hyomandibula is tightly fixed to the medial surface of the preoperculum supporting it (Nursall 1999b). The hyomandibula is more or less exposed above the preoperculum depending on the reduction of the upper part of the preoperculum. The exposed part of the hyomandibula is almost as large or even larger than the remaining preoperculum in advanced pycnodonts such as $\dagger$ Coelodus, $\dagger$ Stemmatodus, $\dagger$ Tepexichthys, and $\dagger$ Pycnodus. The upper part of the hyomandibula of primitive pycnodonts such as $\dagger$ Mesturtus and $\dagger$ Brembodus is broad and flattened in lateral view. It articulated with an elongated and narrow facet on the neurocranium. This morphology limited rotation of the hyomandibula in more primitive pycnodonts. An articulation process was developed at the antero-dorsal edge of the hyomandibular head in †Gyrodus, †Iemenja, and $\dagger$ Neoproscinetes mediating rotation mainly around it. Thus, rotation of the suspensorium was more efficient in more advanced pycnodonts. The opercular process of the hyomandibula was reduced in almost if not all pycnodonts. Lambers $(1991,1992)$ indicated a vestigial opercular process in †Gyrodus spp., which has not been observed herein.

The exposed upper part of the hyomandibula exhibits irregularly arranged tubercles or ridges in most pycnodonts similar to the sculpture of 


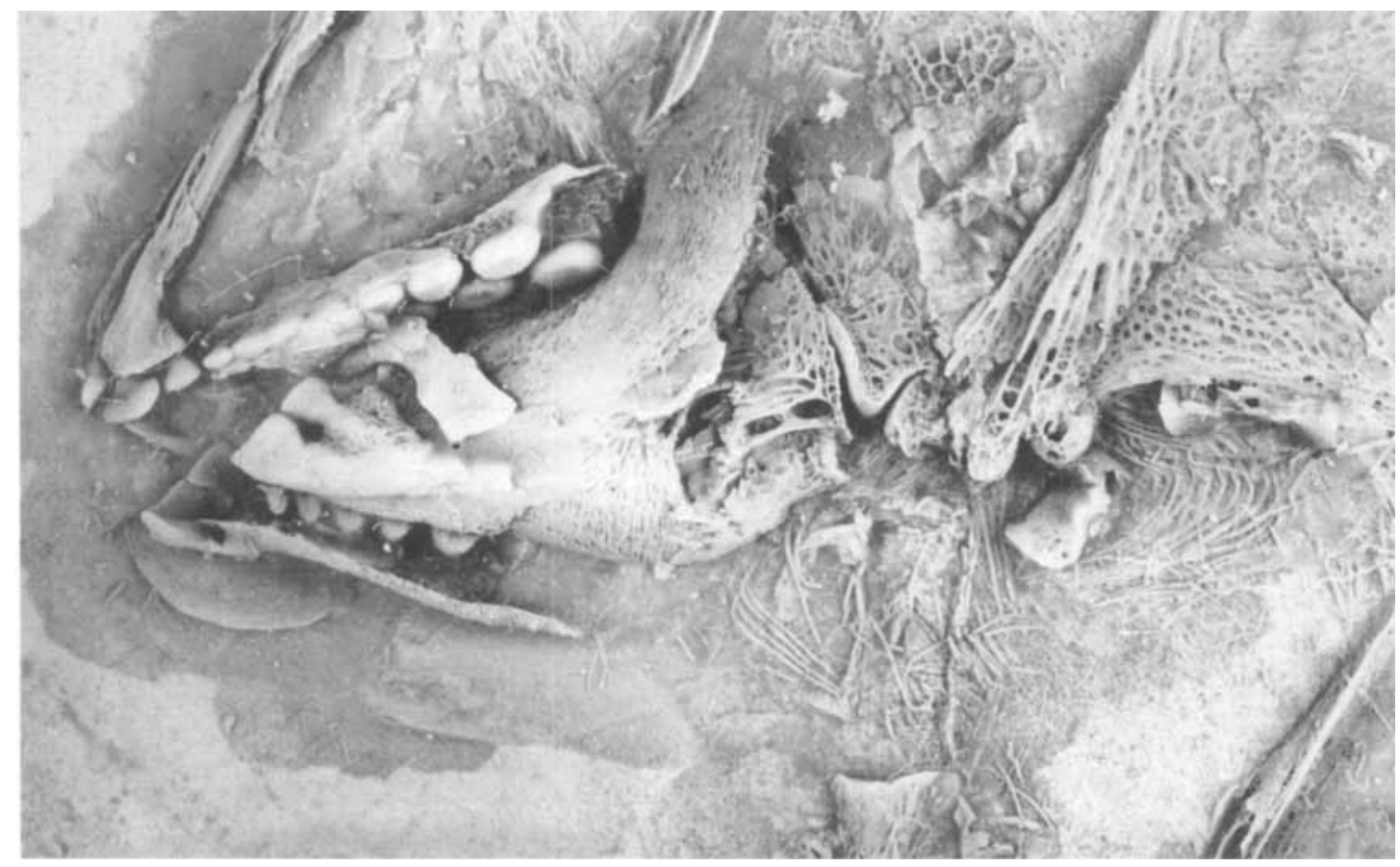

A

$5 \mathrm{~mm}$

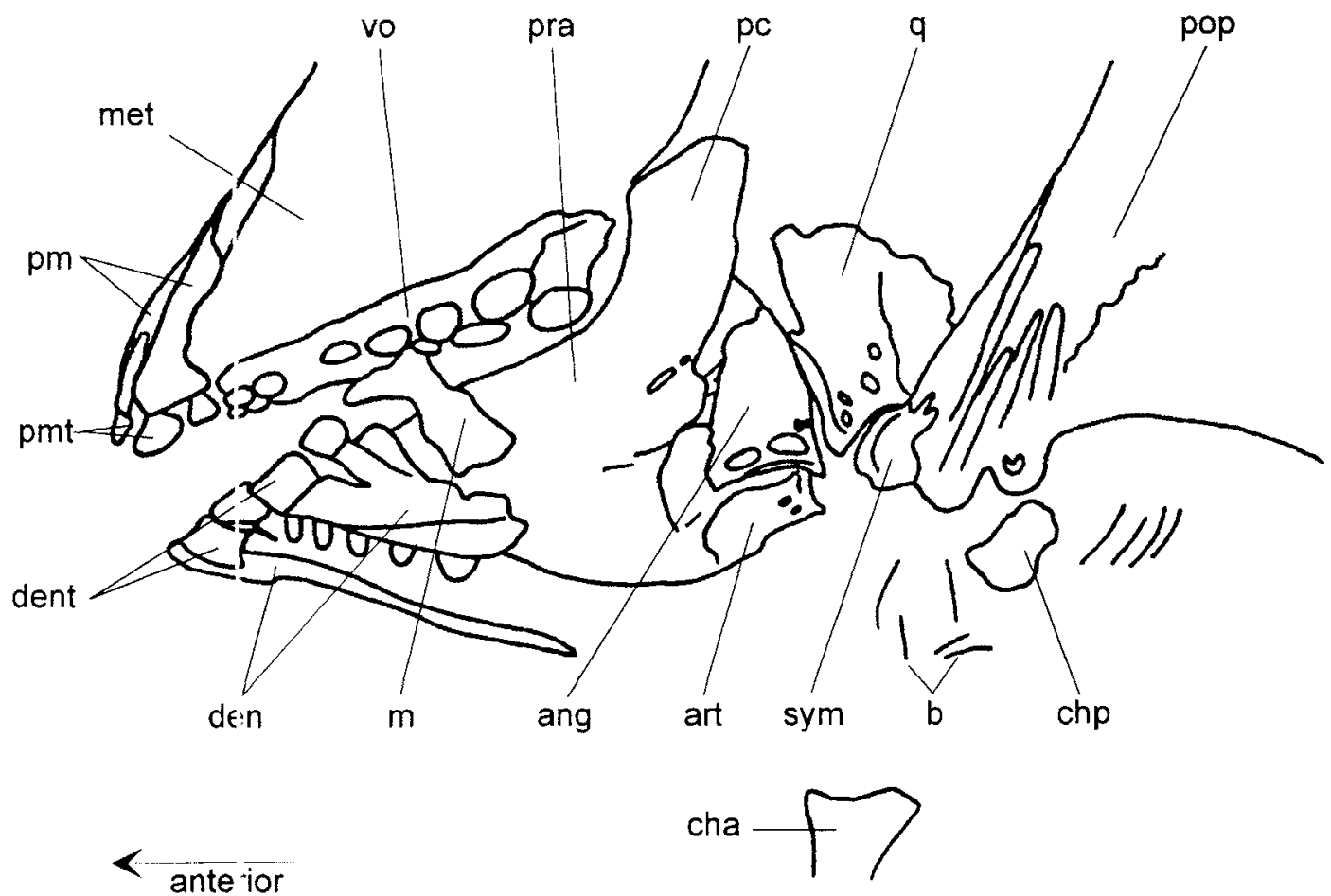

B

Fig. 2. Mandibular articulation of pycnodonts (A) and its drawing (B) exemplified by Pychodus platessus (BMNH P. 1634) displaying the two articulation pairs. Acid prepared specimen from the Eocene of Monte Bolca, Northern Italy. The symplectic abuts the quadr tte and there is an additional articulation surface between both (arrow).

ang. angular bone: art. articular bone: b. remains of branchial rass. cha. anterior ceratohyal: chp, posterior ceratohyal; den, dentalosplenial: dent. tecth of dentosplenial: m. maxilla: met. mesethmoid bone; pc. processus coronoideus; pm, premaxilla; pmt. premaxillary teeth: pop. preoperculum: pra. prearticular bone: q quadrate: sym, symplectic; vo, vomer. 
the dermal bones. This dermal-like pattern of the hyomandibula was suggested to present some kind of dermalisation by Nursall (1996b, 1999a, b), and he consequently called this part of the hyomandibula dermohyomandibula. However, this sculpture is only superficial, and the hyomandibula is an endochondral bone. Subsequently, the dermal-like pattern rather corresponds to membranous outgrowth than to a true dermalisation, and the term dermohyomandibula implies wrong homologies. Membranous outgrowth on the anterior or posterior region of the hyomandibula is found in many advanced actinopterygians (G. Arratia, pers. comm.). Thus, the term proposed by Nursall (1996b) is not retained herein. The development of the membranous outgrowth of the upper part of the hyomandibula in pycnodonts is related to the reduction of the preoperculum, since only the exposed hyomandibular parts show the dermal-like structure. The development of membranous outgrowth reflects a change in an existing structure rather than the development of a new bone with any implied homology. The sculptured part of the hyomandibula was mostly misinterpreted as operculum (e.g., Blot 1987) or dorsal preoperculum (Wenz 1989a).

The symplectic articulates with the antero-ventral edge of the medial surface of the preoperculum (Figs 1B, 2A, B). The symplectic was probably fixed to the preoperculum by connective tissue. This condition is different to that found in many other neopterygians, in which the symplectic is not in contact with the preoperculum. The symplectic and quadrate are slightly inclined antero-ventrally to the hyomandibula in pycnodonts.
The elongation of the suspensorium of pycnodonts is related to the shortening of the lower jaw and the placement of the quadrate-mandibular articulation below the orbit and not posterior to it as in primitive actinopterygians.

Opercular apparatus: The opercular apparatus of pycnodonts is reduced compared to that of other neopterygians (Fig. 1A, B). The series is composed of a large and more or less triangular preoperculum (above described), an operculum fixed to the postero-dorsal border of the preoperculum, and two short acinaciform (slender) branchiostegal rays, which articulate with the ceratohyal elements. The operculum is small. narrow, and dagger-shaped in almost all pycnodonts. TPycnodus is the only pycnodont, that lacks an operculum. The functional significance of the reduction of the operculum is unclear (see below).

There is no subopercular bone in pycnodonts. The interoperculum developed in association with a mobile maxilla and a forwardly directed jaw articulation in the evolution of actinopterygians towards the characteristic halecostome suction feeding (Schaeffer \& Rosen 1961, Lauder $1980 \mathrm{~b}, 1982$ ). Thus, the interopercular bone is a key element in the chain of elements transmitting contraction of the levator operculi muscle to the mandible (Lauder 1983). Subsequently, the absence of the interoperculum and the associated interoperculo-mandibular ligament in pycnodonts indicates that there must have been another way to transmit the forces from the opercular apparatus to the mandible.

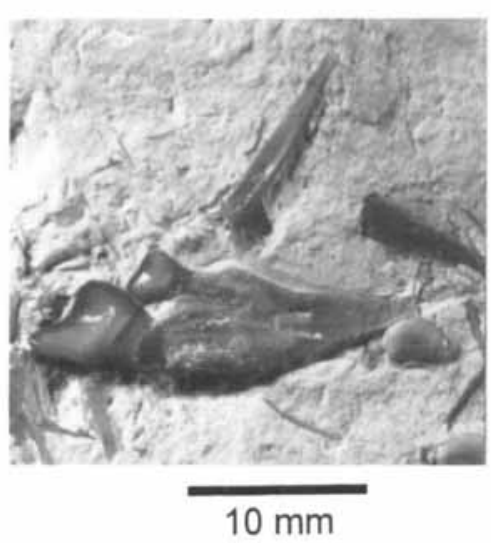

A

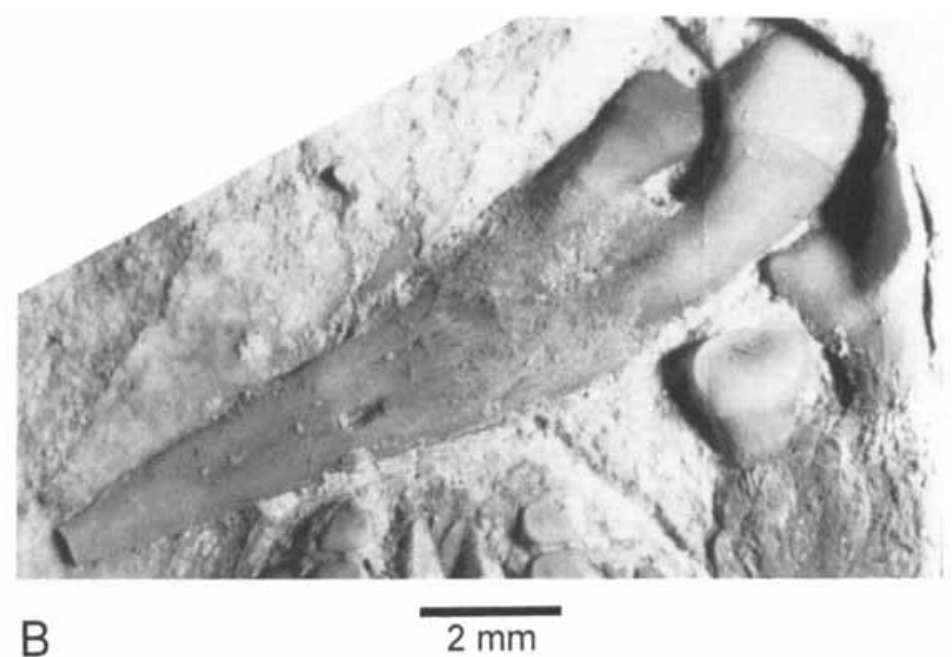

Fig. 3. Jaw elements of $\nmid$ Proscinetes elegans (Agassiz 1833) from the Kimmeridgian (Upper Jurassic) of southern Germany showing foramen of mandibular sensory canal. A. Premaxillae (BSP-1885 IX 61). B. Right dentalosplenial (BSP-1885 IX 60). 
The reduced number of branchiostegal rays in pycnodonts is striking. A reduced number is also found in some primitive actinopterygians such as haplolepids, redfieldiiforms, saurichthyids. and lepisosteiforms (Lambers 1991) and some teleosts (McAllister 1958). However. the lowest number found in other actinopterygians is generally three. Acinaciform rays are also present in $\doteqdot$ Macrosemius and †Propterus (Bartram 1977) and advanced eleosts (McAllister 1968). The reduction of the branchiostegal rays to two short elements in pycnodonts indicates a small branchiostegal membrane and suggests relative small potential for opercular chamber expansion.

The branchial opening of pycnodonts was high but rather narrow, probably because of the foreshortened skull and the reduced operculum.

Jaw apparatus: The jaw apparatus of pycnodonts is unique. The upper jaw consists of paired premaxillae and maxillae as in other actinopterygians (Fig. 1A, B). But the premaxillae bear a
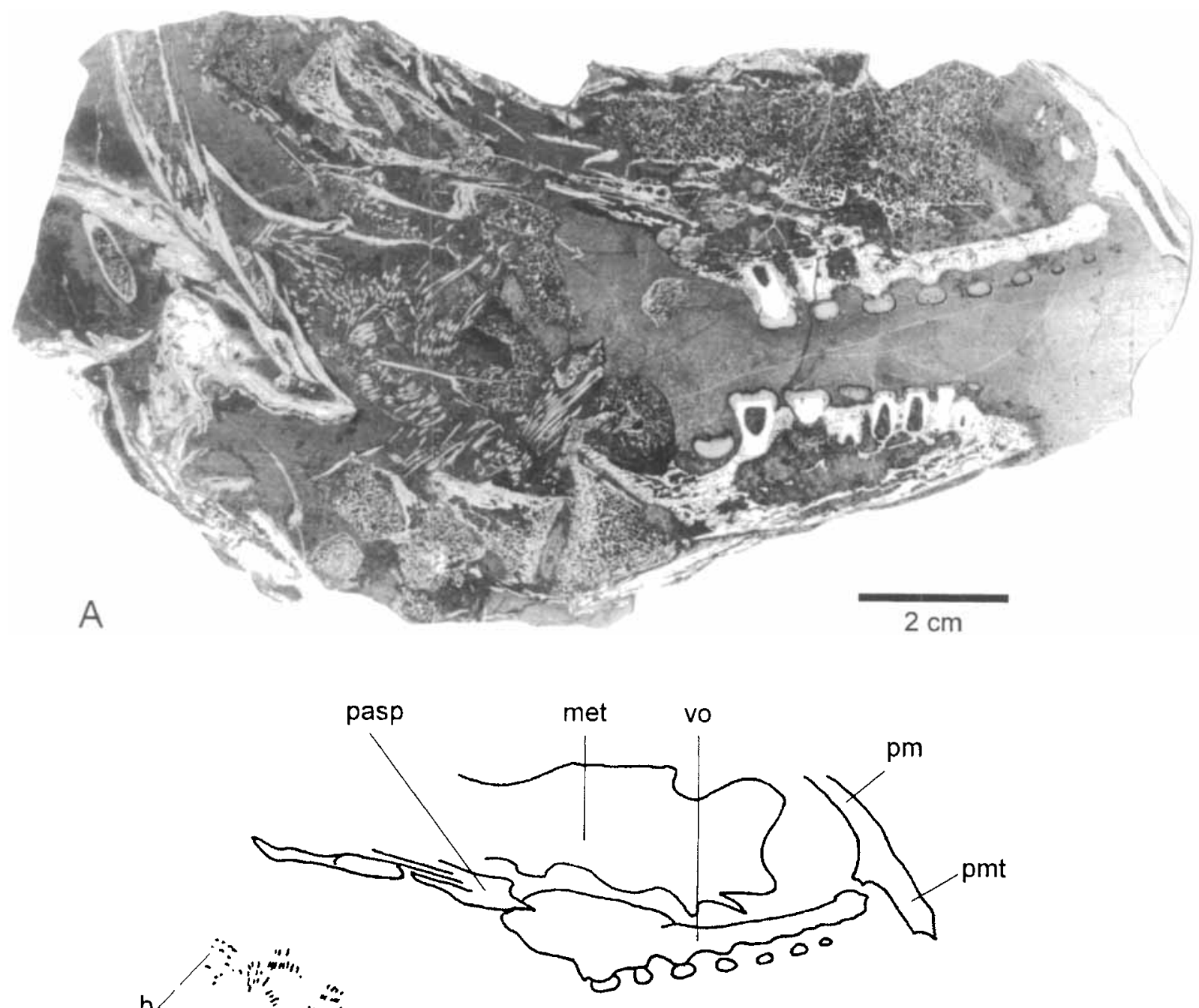

B
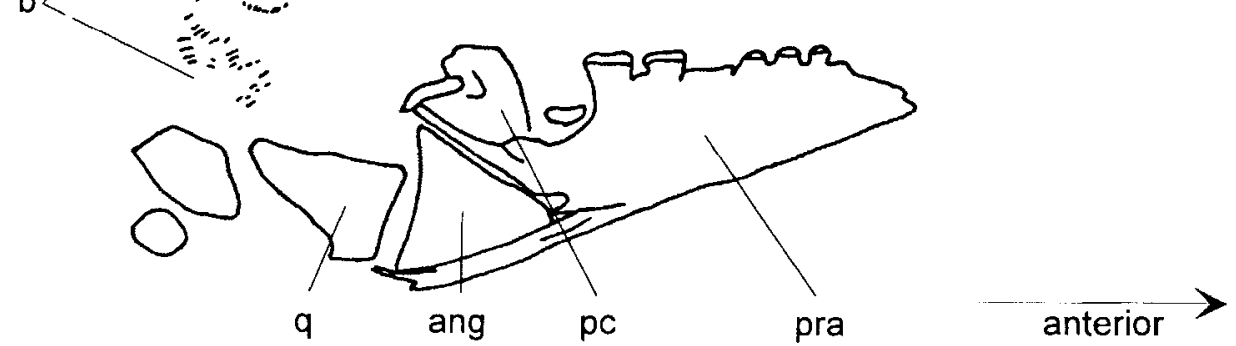

Fig. 4. Vertical section $(\mathbf{A})$ and its drawing $(\mathbf{B})$ through an isolated and fragmentary skull of $\dagger$ Gyrodus sp. from the Oxfordian (Liper Jurassic) o' Chile displaying internal characters and articulation between vomer and premaxilla. For further explanations sec text.

ang. angular bone b. remains of branchial arches: met. mesethmoid: pasp. parasphenoid: pe, processus coronoideus; pm, premaxilla: pmt. pe emaxillary tooth: pra. prearticular bone: q. quadrate: vo. vomer. 
single row of styliform or chisel-shaped grasping teeth, whereas the maxillae are edentulous, as in most durophagous fishes. The lower jaw is composed of dentalosplenials, prearticulars, angulars, and articulars (Figs 1A, B, 2).

The premaxilla is composed of a tooth-bearing portion and the ascending premaxillary process (Fig. 3A). The ascending premaxillary process roofs the snout anteriorly and covers one third of the length of the anterior mesethmoid edge in advanced pycnodonts. In some primitive pycnodonts it is rather short and covered by the dermethmoid bone or dermal tesserae (e.g., $\dagger$ Gyrodus, $\dagger$ Arduafrons, and $\nmid$ Mesturus; Fig. 1A). There is some confusion about the homology of the nasal process of the premaxilla within neopterygians, e.g., in Amia (Grande \& Bemis 1998). The nasal process of Amia forms the most profound part of the nasal cavity. But in pycnodonts, the process is completely superficial and is actually like the superficial position of the ascending process of teleosts. There is no articular process of the premaxilla in pycnodonts. In advanced teleosts, the articular process of the premaxilla is well-developed and articulates with the premaxillary process of the maxilla forming the protrusible upper jaw. Nursall (1999b) reported, that the connection between premaxilla and mesethmoid was not tight in $†$ Macromesodon macropterus (BMNH 37109). This assessment was based on $\mathrm{X}$-ray photographs. In addition to this, a vertical section through an isolated skull of tGyrodus sp. from the Oxfordian of Chile was prepared to elucidate the topology of cranial elements (Fig. 4). It shows, that the ascending process of the premaxillary bone is loosely attached to the anterior surface of the mesethmoid bone with some kind of articulation or attachment between the premaxilla and the anterior edge of the vomer. No nasal depression is found on the snout to fix the premaxillary process as it is found in several advanced teleosts (e.g., Nanididae). The morphology of the premaxilla of primitive teleosts differs from that of pycnodonts. The premaxilla of 'pholidophorids' and †Leptolepis is small, and the ascending process is rather short, similar to the condition found in $\dagger$ Mesturus. Nevertheless, it is assumed, that the premaxilla of these teleosts was already mobile (e.g., Patterson 1977, Lauder 1982). The premaxilla has become secondarily firmly fixed to the neurocranium in several predaceous teleosts as Hoplias and Salmo (Lauder 1982).

The maxillae of pycnodonts are easily lost after death due to their loose attachment on the lateral surface of the skull. In some pycnodonts, the ventral margin of the maxillae is concave or deeply notched. Generally, the maxillae were anchored anteriorly by an articular peg. The articular peg fits into a shallow indent posteriorly to the premaxilla in most pycnodonts, with the exception of †Mesturus spp. and probably †Arduafrons sp., where the maxilla is rather narrow and long without any anterior articulatory peg. Comparison with Recent teleosts with similar dentitions (e.g., sparids, acanthurids) indicates the possibility, that the maxilla was fixed posteriorly to the mandibular arch by a ligamentum maxillomandibulare.

The lower jaw is suspended from the suspensory apparatus by the quadrato-symplectic-mandibular joint (Figs 1B, 2). The mandible is short compared to that of primitive actinopterygians. and the prearticular makes up most of the mandibular arch. It was called "splenial" in the past (e.g., Lambers 1991) but may be the result of the fusion of the splenial, a prearticular portion, and probably coronoids. The paired prearticular bones form a more or less pronounced basin, in which the flat or convex oral surface of the vomerine dentition accurately fits during mandibular abduction. Both prearticulars meet medially along a long and vertically oriented symphysis, which is either rather short (e.g., $\dagger$ Hadrodus) or very long (e.g., †Anomoeodus and †Temanja). Thurmond (1974) assumed, that both prearticulars were not tightly fixed and proposed a lateral adductive/abductive mandibular action. However, Nursall (1999b) suggested that the prearticulars were tightly fixed and rejected the interpretation of Thurmond (1974). But the surfaces of the symphysis shows a rugose pattern indicating the presence of some kind of connective tissue allowing some lateral movements during mouth closure.

The dentalosplenials are rather slender and are firmly sutured antero-ventrally to the prearticulars in pycnodonts during life but got easily disarticulated and lost after death (Fig. 3B). The angulars cover the postero-lateral portion of the mandible (Figs 1A, B, 2). The articulars lie medially to the angulars. There is no independent retroarticular ossification.

Distinct coronoid ossifications are not present in pycnodonts. A distinct and stout process is tightly fused postero-lateral to the prearticular bone (Figs 1, 5). This process is usually called coronoid process, although the bones included in the coronoid process are different in actinopterygians. Consequently, the coronoid process of pyc- 

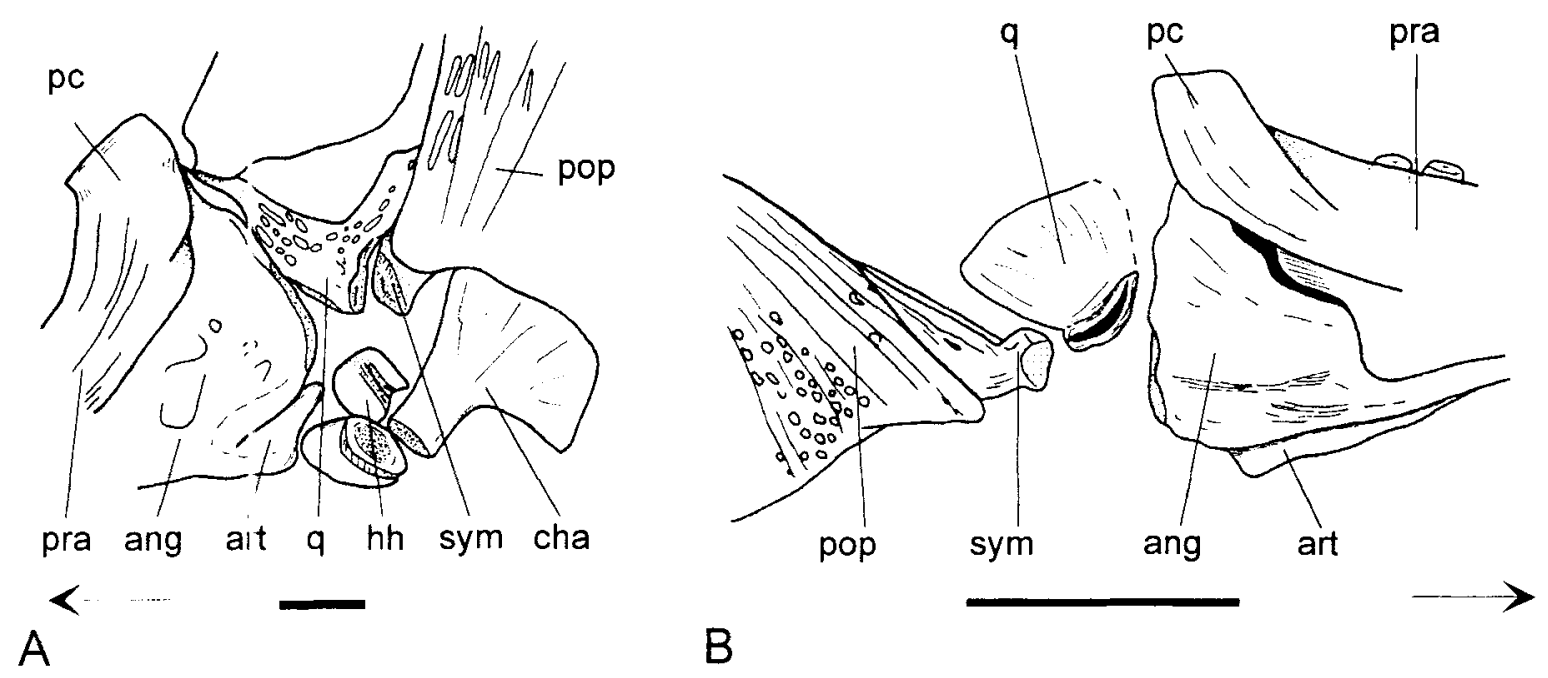

Fig. 5. Mandibular articulation in some pycnodonts. A. † Macromesodon sp. (BMNH P.11774), left side. B. †Macromesodon sp. (BMNH 37109), right side. Scale bars $=5 \mathrm{~mm}$. Arrows point to anterior.

ang, angular bone art. articular bone: cha. anterior ceratohyal: chp. posterior ceratohyal; den, dentalosplenial; enp, endopterygoid: hh. hypohy.1: io. infraorbital: mpt. metapterygoid: m. maxilla: pc. processus coronoideus; pop, preoperculum; pra, prearticular bone: q. cuadrate: sym. symplectic.

nodonts is not homologous to that of "palaeoniscoids" or telecists. The presence of a coronoid process was considered a neopterygian synapomorphy by Gardiner (1984). However, a well-developed "coronoid process" was demonstrated for primitive 'palaeoniscoids' by Gardiner (1967) and Gottfried (1992). This contradicts the assumption of direct correlation between presence of a 'coronoid process' and a free maxilla in 'subholosteans' as proposed by Schaeffer (1956).

The mandibular articulation in pycnodonts is special, with similarities to the mandibular articulation of halec smorphs (Nursall 1996b. 1999a. b. Kriwet 1999a, 2001). For descriptions of the mandibular articulation of halecomorphs compare Patterson (1973), Olsen (1984), and Grande \& Bemis (1958). In contrast to halecomorphs, both quadrate and symplectic take part in the mandibular ar iculation in pycnodonts with the quadrate lying vertical to the symplectic and both are genesally closely arranged in the same plane (Figs 2. 4, 5). The similarity between amiids and pycnodonts in mandibular articulation is, that both quadrate and symplectic are involved. But ir amiids, the quadrate articulates with the anteri or articular element (Bridge's ossicle ' $c$ ') and the symplectic with the posterior one (Bridge's ossicle ' $\mathrm{d}$ '), the whole complex being invested with : well-developed articular capsule. This articular sapsule may have been also present in pycnodints.

Pycnodonts have been defined by their unique tooth morphology and arrangement. Teeth are restricted to the unpaired vomer in the roof of the mouth and the paired prearticulars, premaxillae. and dentalosplenials (Figs 1A, B, 3, 6). The teeth are rigidly fixed to these bons. Sometimes, the teeth are embedded in shallow depressions or sit on small bony elevations. There is only a single generation of teeth; the teeth are not replaced (Kriwet 2001).

Each premaxilla and dentalosplenial bars a single series of few styliform or incisiform teeth (Fig. 3). The vomerine and prearticular teeth are molariform and generally arranged in longitudinal rows forming a more or less dense pavement (Fig. 6). Usually, there is a distinct main tooth row, which is characterised by the largest teeth and a varying number of medial and lateral tooth rows.

Hyoid apparatus: The morphology of the hyoid arch of pycnodonts corresponds to the general pattern found in non-teleostean actinopterygians. It consists of a single hypohyal, an anterior and a posterior ceratohyal, and an interhyal (Fig. 1A, B). The anterior ceratohyal supports the two branchiostegal rays on each side of the head. It is generally short with a notched ventral margin and a plate-like posterior portion in lateral aspect. The anterior ceratohyal of pycnodonts is very similar to that found in several teleosts and macrosemiids (Bartram 1977, Lambers 1991), but the pycnodont one is smaller in respect to the skull and more irregular. The hypohyal and the rod-like interhyal are also small 


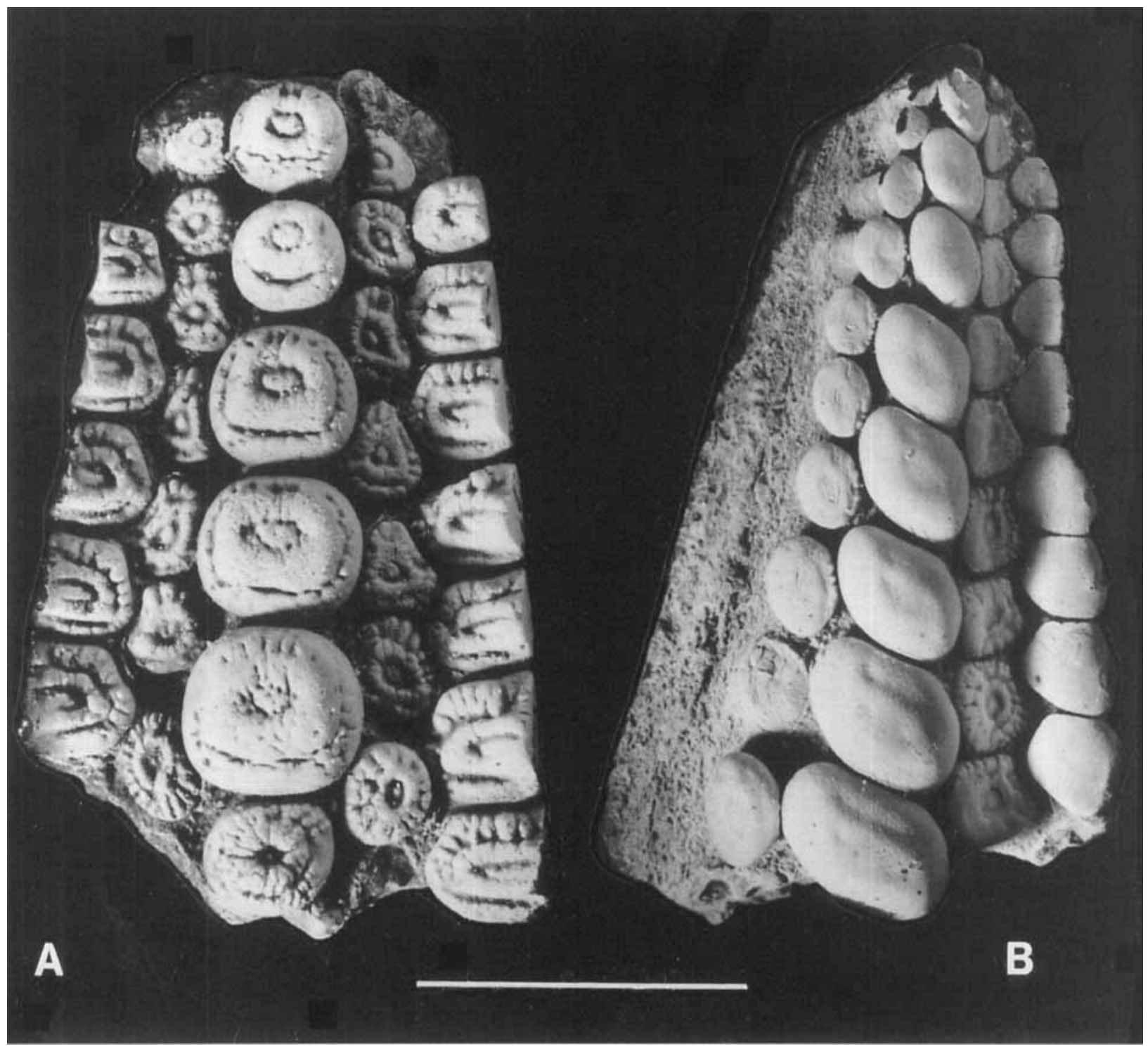

Fig. 6. Isolated dentitions of $\dagger$ Gyrodus planidens Woodward 1895 (MB. f.7173) from the Upper Jurassic (Tithonian) of Weymouth, England. A. Vomerine dentition. B. Right prearticular dentition. Scale bar $=10 \mathrm{~mm}$.

but generally well-ossified. The attachment of these bones to each other or to any part of the suspensorium and/or opercular apparatus is unclear but may have been articulated via broad cartilaginous surfaces with each other as it is found in many extant actinopterygians. There may have been ligamentous connections between the hyoid arch and the mandible, the suspensorium, and/or pectoral girdle.

There is no epihyal, basihyal, and urohyal in pycnodonts.

Branchial apparatus and branchial teeth: The branchial skeleton and its associated elements vary among fossil and extant actinopterygians. The branchial chamber is closely associated with respiration and feeding and the associated muscles play important roles during deglutition. Unfortunately, their branchial skeleton is badly preserved due to disarticulation and other taphonomic processes. Therefore, information is very limited, and it is impossible to reconstruct the branchial skeleton of pycnodonts. Traces of gill filaments and branchial arches are found in many specimens, both mechanically and acid prepared (Fig. 4A, B). The ceratobranchials are easily discernible. They are U-shaped in cross section, the U opening posteriorly. Gill filaments arise from the hollow of the $\mathrm{U}$. There are five ceratobranchials present. Other structures and elements may correspond to the pharyngo-. epi-, and hypobranchials. But they are too scattered for accurate identification. The best preserved structures found in the branchial chamber of pycnodonts are branchial teeth (Kriwet 1999b, 2001). 


\section{Myology, ligarients, and arthrology}

The knowledg: of the myology, the arrangement of ligaments, and the joints or couplings between bony structure; are also important to understand the kinematics during feeding. Unfortunately, the reconstruction of soft tissues in exclusively fossil known taxa is speculative as mentioned above. Nevertheless, there are many osteological related features like tuberosities. crests, grooves. fenestrae, fossae, fo amina, and septa and the absence of bones (e.g. interoperculum. urohyal) that allow some assestions about soft tissue anatomy.

Myology: The interpretation and reconstruction of soft tissues and joints related to feeding in pycnodonts are based on the situation in Amia and tele osts. because pycnodonts are hy- pothesised to be the sister group to halecostomes + the fossil aspidorhynchiforms within neopterygians (Kriwet 2001). In addition, the soft tissues and the arrangement of muscles and ligaments in the skull of extant sparids, acanthurids, nandids, and Anarrhichas lupus, which are assumed to be similar to pycnodonts in their dentition and to some extent also in their skull-shape, and some extant ram-feeding teleosts (e.g., Amia, Lamprologus) have been studied for comparison (Fig. 7). A tentative reconstruction of the superficial head musculature participating in feeding of pycnodonts is presented in Figure 8 based on these comparisons. It is assumed, that pycnodonts possessed at least a tripartite adductor mandibulae with the superficial part of the $\mathrm{m}$. adductor mandibulae (Fig. 8: $A_{1}$ ) originating from the straight anterior margin of the preoperculum and the
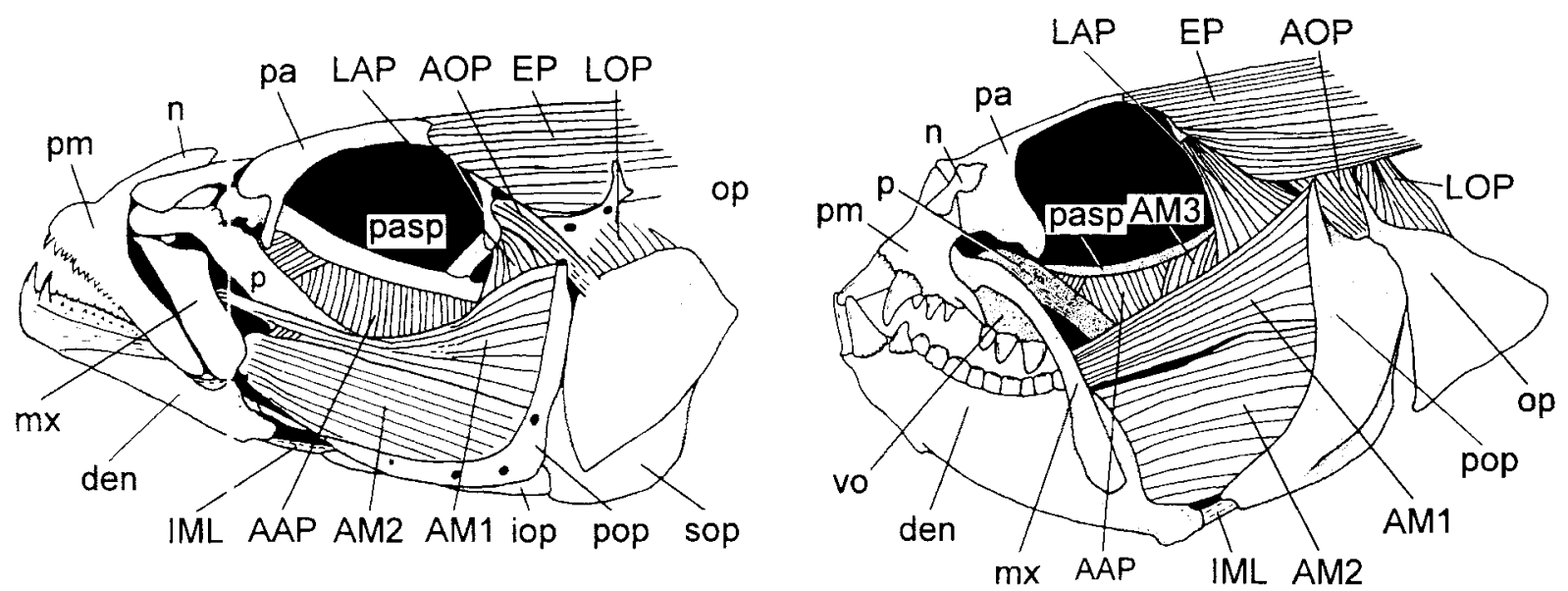

A

B

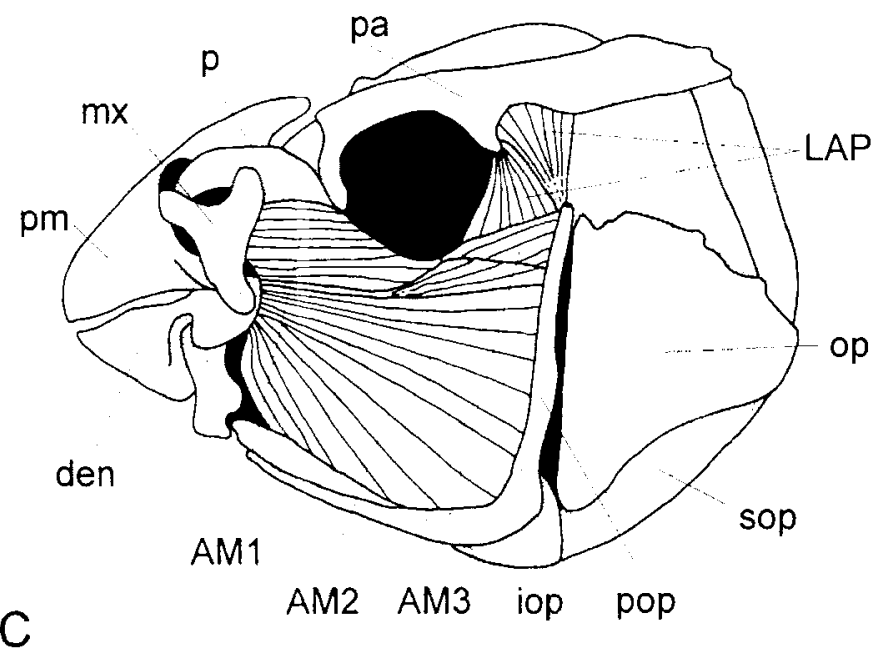

Fig. 7. Lateral head musculature of different teleosts. A. Lamprologus attonuatus. a ram feeder. Modificd after Liem (1993). B. Anarhichas laj'us, a shell crusher. Modified after Dobben (1937). C. Scarus rubroviolaceus, a herbivore actinopterygian. Modilied after Clcments \& Bellwood (1988).

AAP. adductor arrus palatini muscles: AM1. AM2. AM3. divisions of the adductor mandibulac muscles; AOP, adductor operculi muscle: den. dentalosplenial: EP. epaxial muscles: IML. interoperculo-mandibular ligament; iop, interoperculum; LAP, levator arcus pala ini muscle: L.OP. levator operculi muscle: mx. maxilla: n. nasal bone: op. operculum: p. palatine arch; pa, parietal bone: pasj' parasphenoid: pm. premaxilla: pop. preoperculum: sop. suboperculum: vo, vomer. 
head of the hyomandibula, whereas the other parts of the adductor mandibulae muscles must have been inserted on the angular bone and probably along the postero-lateral surface of the prearticular bone. An indication for this is found in †Anomoeodus spp., where the lateral (oral) border of the long prearticulars is rather broad and exhibits a rugose surface. There is no reason to believe, that the adductor muscles were not expanded above the suspensory apparatus onto the side of the cranium as in extant shell-feeders with deep skulls (e.g., Anarrhichas).

Nursall (1999a) reconstructed a very large palatine arch muscle group consisting of levator and adductor palatini, protractor and adductor hyomandibulae, and levator and dilatator operculi muscles in pycnodonts without distinctive hyomandibular head (e.g., Mesturus, Arduafrons). This muscle complex originated from the massive prootic and sphenotic and inserted on operculum, pterygoquadrate arcade, and hyomandibula. There are only minor traces of muscle attachment on the sphenotic and prootic bones in pycnodonts with hyomandibular condy- lar process (pers. obser. in Iemanja). This may indicate, that those pycnodonts had a less developed palatine muscle complex. The palatine muscle complex is important for feeding and respiratory in actinopterygians (e.g., Winterbottom 1974, Lauder 1980b) and assisted ingestion and swallowing of prey. However, the size of the palatine muscle complex is an adaptation to the available space (Osse 1969).

There are two muscles (adductor and levator muscles) between the neurocranium and the opercular apparatus, that mediate the motion and rotation of the opercular apparatus in Recent actinopterygians. The condition of muscle insertion, which are responsible for motion of the suspensorium and related bones is different in teleosts, where they inserted on the medial surface of the large and free operculum, and in pycnodonts, where the operculum is small and sutured to the postero-dorsal margin of the large preoperculum. In addition, the preoperculum is tightly fixed to the underlying hyomandibula. Therefore, I hypothesise, that the insertions of most of the adductor and probably the

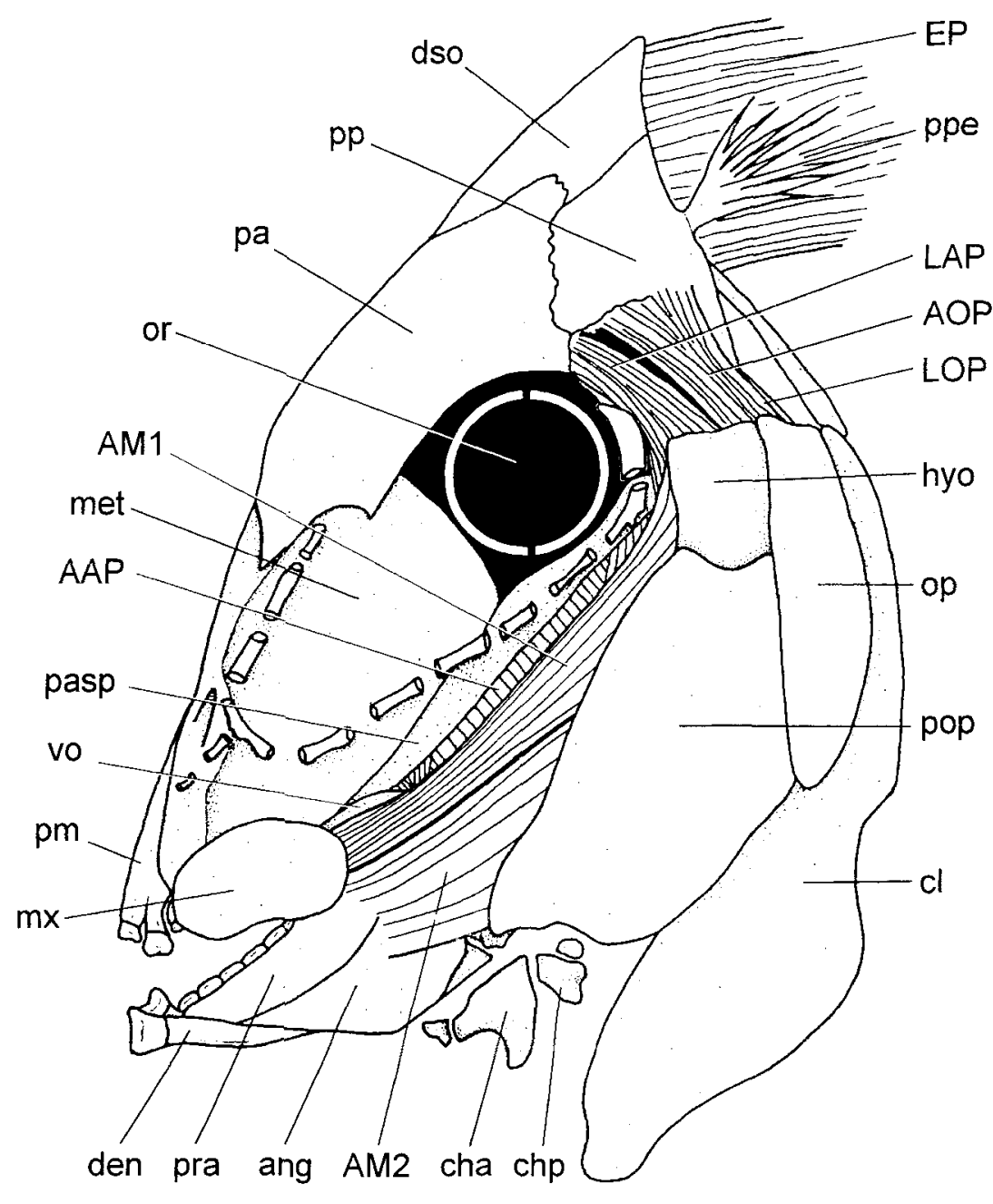

Fig. 8. Tentative restoration of lateral head musculature of a generalised advanced pycnodont. The adductor mandibulae muscles of pycnodonts such as $\dagger$ Mesturus and $\dagger$ Gyrodus are covered by skull elements and not exposed.

AAP. adductor arcus palatini muscles; AM1, AM2, divisions of the adductor mandibulae muscles: ang. angular bone; AOP, adductor operculi muscle: cha, anterior ceratohyal; chp. posterior ceratohyal: cl, cleithrum: den, dentalosplenial; dso, dermosupraoccipital: EP, epaxial muscles: hyo, hyomandibula: LAP, levator arcus palatini muscle: LOP, levator operculi muscle; met, mesethmoid bone: $\mathbf{m x}$, maxilla: or. orbit; op. operculum; pa, parietal bone; pasp, parasphenoid; pm, premaxilla: pop, preoperculum; pp. postparietal bone: ppe, postparietal process; pra, prearticular bone; vo, vomer. 
complete levator muscles have been shifted from the dorsa 1 margin of the operculum to the head of the hyomandibula and the upper edge of the preoperculum (Fig. 8). Consequently. a distinct levator muscle, which originated from the operculum. was not developed. This is especially evident $\mathrm{n} \uparrow$ Pycnodus. which lacks the opcrculum completely and is supported by the presence of rugosities and small crests on the medial surface of the hyomandibular head in pycnodonts.

The opercul ir process also plays an important role in expancing the buccopharyngeal cavity in teleosts, because it assists in abduction. adduction, and rotation of the operculum. But pycnodonts lack an ispercular process for muscle insertion.

Consequently, the hyomandibula must be regarded as a mijor key element in expanding the buccopharynge al cavity in pycnodonts. because most of the muscle masses (c.g.. m. adductor hyomandibular:), that mediate the rotation and motion of the opercular apparatus and suspensorium originate and insert from the well-developed hyomancibula.

The ventral head muscles of pycnodonts were possibly different in arrangement and development from those of other neopterygians, since the prearticulırs are large and fused along a long symphysaal line. For instance. it is suggested, that the m. hypohyoideus has never been developed or was secondarily reduced. bccause pycnodonts laik a suboperculum (Kriwet 2001). But pycnodonts certainly had a muscle mass similar to the sternohyoideus. The $\mathrm{m}$. sternohyoideus is generally a large muscle. that lies deep to the superficial layer of the ventro-lateral muscles in extant teleosts. It originates from the cleithrum and in serts on the urohyal. It is rather speculative to assume a sternohyoid muscle for pycnodonts, because they lack an urohyal. However, a similar muscle mass must have been present, that un ted the pectoral girdle and the hyoid apparatus to mediate the posterior-directed translation of the hyoid apparatus during mandibular $d \in$ pression. I hypothesise. that there was a small ar $d$ short muscle. that connected the both dentalosplenials at the anterior part. which was similar to the $\mathrm{m}$. intermandibularis portion of the geniolyoid muscles of extant halecostomes.

The reconstruction of muscles, that originatc from or inser on the pectoral girdle is rarely possible due $t$ ) the preservation of most pycnodont specimens. It is assumed here, that the pec- toral girdle was mainly fixed by ligaments to the neurocranium; only minor indication of muscles have been found so far in Gyrodus, Iemanja, and Coelodus (e.g. typical rugosities).

The epaxial musculature plays an important role in cranial elevation during mouth opening. It generally extents anteriorly on the dorsal surface of the neurocranium in living neopterygians, e.g.. Scarus spp., Anarrhichas. In pycnodonts, epaxial muscles were attached to the medial surfaces of the large post-temporal fossae and the lateral sides of the supraotic crest, at least in pycnodonts without caudally directed postparietal brush-like processes such as $\dagger$ Arduafrons, $\dagger$ †rrodus, †Mesturus, and †Micropycnodon. Nevertheless, the lateral surfaces of the supraotic crest exhibit almost no traces of muscle attachment. Many pycnodonts have postparietal processes (postparietal peniculus of Nursall 1996b), that are brush-like and fixed to the medial surface of the postparietal bones. They represent osseous extensions of occipital tendons and have formed an attachment for the upper, anteriorly directed extension of an anterior myoseptum (Nursall 1999b). Thus, the postparietal processes would have increased and concentrated the contractile forces of the anterior epaxial myomeres, resulting in cranial elevation.

Ligaments: The reconstruction of ligaments is extremely difficult, because the osteologically related features such as tuberosities, crests, grooves etc. are almost always obscured by fractures or sediment. However, the anatomy of the skull provides some information on the ligamentous network (e.g., maxillo-mandibular).

The maxilla of most pycnodonts was not firmly fixed to the cheek, but was mobile in many pycnodonts. The mobility and movement of the maxilla during mouth opening and mouth closure is supported and augmented by the ligament maxillo-mandibular (= ligamentum primordiale) in teleosts. There is no reason to believe the condition in pycnodonts to be different from that of teleosts. I suppose, that the maxillo-mandibular ligament originated at the posterior margin of the maxilla and inserted on the mandible in the region of the coronoid process. The ligament follows the abduction of the mandible and becomes taut, pulling the posterior part of the maxilla ventrally. It augments the action of the $\mathrm{m}$. adductor mandibulae during the initial phase of mandibular adduction and conducts the maxilla back to its original position during mouth closing where it is held by the ligament. 
There were certainly also ligaments between the other functional units elements (e.g., hyoid and branchial apparatus). However, a reconstruction of those ligaments is impossible.

Pycnodonts lack an interopercular bone and consequently the interoperculo-mandibular ligament, which connects the mandible to the opercular apparatus. Thus, there is no connection between the jaw and the opercular apparatus as in halecostomes and teleosts. This interpretation is also supported by the reduced size of the preopercle (J.R. Nursall, pers. comm. 2001). A similar condition is also found in primitive actinopterygians like 'palaeoniscoids'.

Arthrology: The suspensorium apparatus of pycnodonts forms a narrow, functional triangle. The three angles are represented by the craniohyomandibular, the palato-cranial, and the mandible-suspensorium joint (Nursall 1996b, Kriwet 2001).

The cranio-hyomandibular joint is similar to that found in Recent teleosts but it is not uniform in pycnodonts, depending on the morphology of the head of the hyomandibula and the associated fossa on the endocranium, e.g., oval in $\dagger$ Gyrodus, circular in $\uparrow$ Neoproscinetes. It is usually synovial with an articulation head on the hyomandibula (e.g., †Iemanja palma, Kriwet 2001). $\dagger$ Mesturus is lacking such an articulation head (Nursall 1999a). The groove for the hyomandibular articulation is formed by the sphenotic and pterotic bones. In contracts, the hyomandibula articulates dorsally into a cartilaginous groove in Amia, that is mostly located under the dermopterotic (Grande \& Bemis 1998).

The palato-cranial joint of pycnodonts differs from that of Amia and teleosts. It is formed by the palatine process of the entopterygoid. The palatinal process of each entopterygoid articulates with the posterior end of the vomer. Usually, the palatine complex articulates with the ethmoid complex and the maxilla and forms a palato-maxillary joint in teleosts, which is absent in pycnodonts.

The mandible-suspensorium joint consists of two articular surfaces of the quadrate and the symplectic bones. This kind of articulation is rather peculiar in pycnodonts and similar to that found in Amia. Both quadrate and symplectic take part in the mandibular articulation (see above).

Other joints are the palato-quadrate-parasphenoid, premaxillo-maxillary, branchial apparatusneurocranium, hyoid-opercular, and hyoid-sus- pensorium joints. The palato-quadrate-parasphenoid consists of the metapterygoid, which articulates anteriorly with the parasphenoid below the orbit in the snout in pycnodonts. This joint is interpreted as synapomorphy of pycnodonts by Nursall (1999b).

The joints of the upper jaw of pycnodonts are different from that of teleosts. The premaxilloneurocranial, the maxillo-prevomerine, and the maxillo-premaxillary joints are not present. The rather short ascending arm of the premaxilla found in some pycnodonts, e.g., tGyrodus and $\dagger$ Mesturus, indicates, that the premaxilla was not mobile but more or less fixed to the cranium. This arrangement probably supports stronger bite. But in most pycnodonts the dorsal ascending arm of the premaxilla is rather long and superficial, not fitting into a rostral fossa on the dorsal aspect of the neurocranium (premaxilloneurocranial joint of teleosts). It is not firmly fixed but free and moves with the maxilla. The joint between premaxilla and maxilla usually consists of an articular process on the anteromedial aspect of the maxilla. A distinct articular process of the premaxilla is lacking.

The branchial apparatus is suspended from the endocranium by the first pharyngobranchial. The junction between the pharyngobranchial and the endocranium was ligamentous or there was connective tissue.

In addition, the junctions between the branchial elements was certainly cartilaginous. The cartilaginous epiphyses are useful to minimise any shock to the branchial system during biting and allows simultaneous movements by the transmission of muscular forces.

The hyoid apparatus of pycnodonts consists of anterior and posterior ceratohyals, a hypohyal, and an interhyal. Each anterior ceratohyal supports two branchiostegal rays. The junctions between these bones to each other or to any part of the suspensorium and/or opercular apparatus were probably ligamentous and/or cartilaginous. But no indications to support such a connection have been found so far.

There is no distinct operculo-hyomandibular joint as in teleosts and in Amia. Nevertheless. Lambers $(1991,1992)$ reported a vestigial opercular process in †Gyrodus, which would mean, that the operculum is free. However, no vestigial opercular process was found during this study. The operculum articulates tightly with the preoperculum. The hyomandibula is fixed to the medial surface of the preoperculum. 


\section{The ecomorphology of the pycnodont skull}

The mode of feeding is especially obvious in the dentition of vertebrates. Usually, the feeding preferences are deduced from the morphology and number of tee $h$. It is generally accepted, that the morphology o an organism is controlled by the environment and that the optimal connection between form and function of an organism and the environment is the result of natural selection. This discovery resulted in the drafting of the ecomorphological paradigm (e.g., Davis \& Birdsong 1973. Barel 1'883). The ecomorphological paradigm, as curre itly accepted, means, that the morphology of the skull relates to how the organism feeds, and accepts a close fit between feeding morphology and prey capture and processing. Thus, interspecific and even intraspecific variation in morphology is correlated to differences in diet.

However. the application of the ecomorphological paradigm: without a broad conceptual framework may lead to misinterpretations. because many ecomorphological studies either treat the ecological sigrificance of morphological appearances without knowledge of their function or endless data sets of various measurements are collected in the hope of finding any significant patterns. Lien (1993) stated, that behavioral parameters of en play a greater role than skull design. But it is not possible to reconstruct the behaviroal parameters of fossil organisms. Therefore. I suggest, that the best way to reconstruct the ecomorphology of a fossil organism is to use the information obtained from the skeletal anatomy of the head and anterior body in combination with the data from soft tissue reconstructions, from the joints between functional units, and from the general shape.

The buccopharyngeal cavity of extant actinopterygians was described as changeable pipe or cone. that can be expanded and compressed in various ways by the action of the muscles, based on functional morphological analyses of the feeding apparatus of teleosts (truncated cone model, e.g.. Osse \& Muller 1980) (Fig. 9). The buccopharyngeal cavity of deep bodied teleosts (e.g., Calamus sp.) can be described as cone-shaped pipe (Fig. 9A). The co-ordinated activity of the epaxial muscles, sternohyoideus, levator arcus palatini. and dilatator operculi muscles in connection with spreading of the branchiostegal membrane results in the explosive expansion of the cone-shaped buccopharyngeal cavity. This produces a steep negative pressure in the buccal cavity. In contrast to that, the buccopharyngeal cavity of ram feeders (most primitive actinopterygians including the 'palaeoniscoids' and predacerous teleosts) is represented by a cylindrically
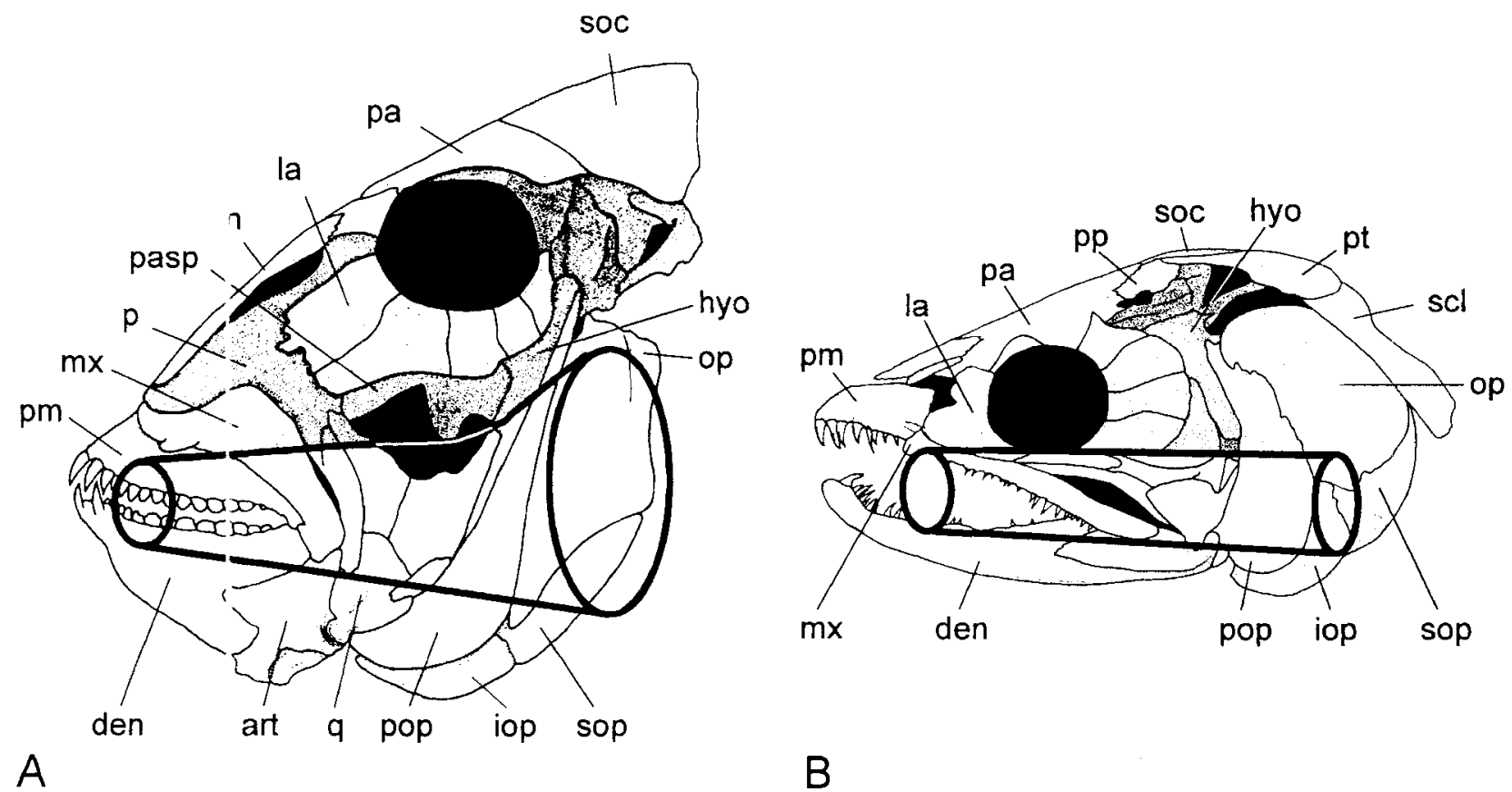

Fig. 9. The morph slogy of the buccopharyngeal cavity of teleosts presented as conc. A. Calamus sp., a shell crusher. B. Salmo sp.. a ram-feeder.

art articular bone: den. dentalosplenial: hyo, hyomandibula: iop. interoperculum: la. lacrimal; mx, maxilla; n, nasal bone; op, operculum: p. pal: tine arch: pa. parietal bone: pasp. parasphenoid: pm. premaxilla: pop. preoperculum; pp, postparietal bone; pt. posttemporal tone: q. quadrate: scl. supracleithrum: soc. supraoccipital bone: sop. suboperculum. 
shaped buccopharyngeal cavity producing very small negative pressures (e.g., Lauder 1980c; Fig. 9B). Compression of the buccopharyngeal cavity is effected by actions of the adductor mandibulae, adductor arcus palatini, and geniohyoideus muscles in extant actinopterygians.

Thus, the basic feeding patterns of actinopterygians are ram feeding, biting, and suction. Many generalised teleosts combine elements of all three patterns in response to the functional demands presented by particular prey, e.g., fixed to the substrate or free-swimming in mid- or surface waters. Liem (1993) proposed suction feeding based on the findings in Hemitilapia oxyrhynchus as generalised morphological pattern. Suction feeding is related to a deep skull, welldeveloped supraoccipital crest for insertion of well-developed epaxial muscles, deep suspensorium to accommodate an elongate and highly differentiated levator arcus palatini muscle, a protrusible upper jaw, rather short mandibles and maxillae, small gape, cone-shaped design of the buccopharyngeal cavity, and a well-developed urohyal in extant teleosts. Teleosts without jaw teeth but with well-developed pharyngeal dentitions show the largest cone-shape (e.g., cichlids). The biting pattern is lost in these teleosts.
The skull of pycnodonts displays most characters typical for suction feeding such as a deep skull with well-developed supraotical crest, a deep and vertical suspensorium, an elongated and highly differentiated levator arcus palatini muscle, a protrusible upper jaw, short mandibles and maxillae, and a small mouth gape. However. pycnodonts lack the urohyal and consequently associated musles (e.g., m. geniohyoideus) and ligaments as they are found in extant actinopterygians. The buccopharyngeal cavity represents a truncated cone when the diameter of the rather small mouth opening is connected with the diameter of the esophagus at the level of the branchial teeth (Fig. 10). The morphology of the truncated cone is very similar to that found in teleosts with strong suction kinematics (e.g., parrot fishes). This would indicate, that pycnodonts may have created steep negative pressures in the orobranchial chamber when the mouth was opened to overtake prey. However, the rather small branchiostegal membrane may have limited the creation of a steep negative pressure during mouth opening. Consequently, suction feeding was not as effective as in comparable extant teleosts.

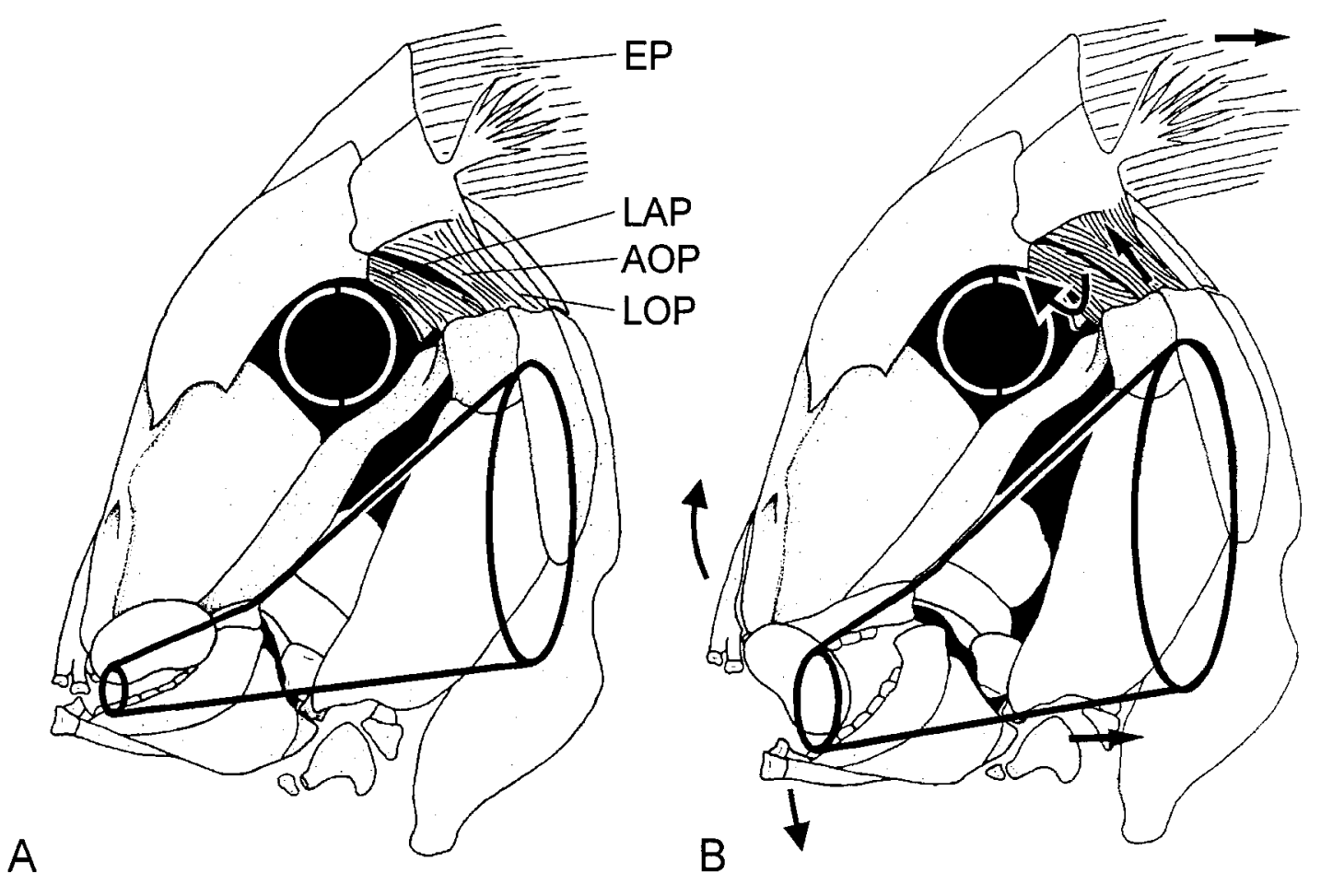

Fig. 10. A. Truncated cone model of a generalised pycnodont while mouth is closed. The small end of the cone terminates at the mouth and the large end deep within the buccopharyngeal cavity. B. Truncated cone model of a generalised pycnodont while mouth opening. Expansion of the buccopharyngeal cavity by rotation of the opercular apparatus and suspensorium creates a negative pressure, drawing water into the mouth. Arrows indicate the dircctions of muscle contraction and movement of associated skeletal elements.

AAP, adductor arcus palatini muscles; EP, epaxial muscles; LAP, levator arcus palatini muscle; LOP. levator operculi muscle. 


\section{Feeding kinematics}

As halecostor es, pycnodonts retained the coupling of primilive actinopterygians (Fig. 11): the epaxial-neuroc anium coupling, that elevates the skull and a ventral coupling involving the hypaxial muscles, cleithrum, and sternohyoideus apparatus. The geniohyoideus was probably absent, because of the lacking urohyal (see above). Cranial kinesis is 1 ather common in actinopterygians (e.g., Schaeffer \& Rosen 1961, Liem 1979) and is related to the actions of mouth opening and closing, especially to the movement of the upper jaw. The postero-dorsally directed rise of the skull is supported by the epaxial musculature of the body. Thu; there are rather large insertion areas for eparial musculature on the posterior neurocranium in extant teleosts. when cranial kinesis is well-developed. Large posttemporal fossae separate $d$ by a median supraotic crest occur in pycnodonts (Nursall 1996b. 1999b. pers. observ.). The intero-dorsal portions of the epaxial myomeric nuscles were fixed to the medial surfaces of th: fossae and the median crest of the supraotic tone probably by occipital tendons similar to the condition found in many extant actinopterygians (e.g. Gemballa 1995). Therefore, it is suggested, that cranial kinesis was also efficient in py znodonts. The brush-like. internal extensions of the postparietals (parietal peniculus of Nursall 1996b. 1999b). that is present in advanced pycrodonts. formed an additional attachment for sollagen fibres from the anterior myosepta and augments the action of the epaxial muscles (Fig. 8 1.

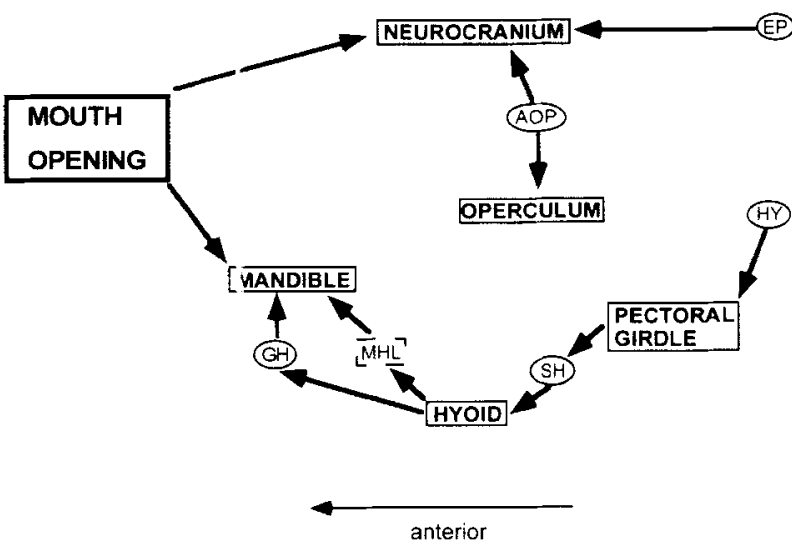

Fig. 11. Structural network in the head of "palaeoniscoids" re lated to mouth or ening and feeding. Solid rectangles: bony elements: paralleligrams: muscles: interrupted rectangles: ligaments. Modified from Lauder (1982).

AOP. adductor oferculi muscle: EP. epaxial muscles: GH. genio-hyoideus muscle: HY. hypaxial (obliquus inferioris) musculature; MHI.. mandibulo-hyoid ligament; SH. sternohyoideus muscle.
Pycnodonts are hypothesised to have developed structural innovations compared to primitive actinopterygians, but which are also found in halecomorphs and teleosts, e.g., palatine arch muscle group consisting of levator and adductor palatini, protractor and adductor hyomandibulae, and levator-dilator operculi muscle group. The arcus palatini muscle, which is absent in primitive actinopterygians (Fig. 11) connects the neu-

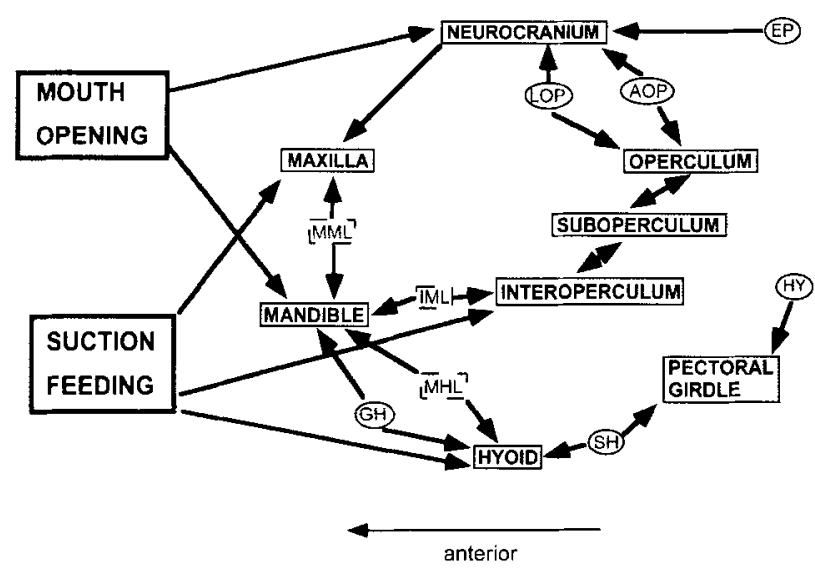

Fig. 12. Structural network in the head of halecomorphs related to mouth opening and suction feeding. Solid rectangles: bony elements: parallelograms: muscles; interrupted rectangles: ligaments. Modified from Lauder (1982).

AOP. adductor operculi muscle: EP, epaxial muscles; GH genio-hyoideus muscle; HY, hypaxial (obliquus inferioris) musculature: IML. interoperculo-mandibular ligament; LOP levator operculi muscle; MHL, mandibulo-hyoid ligament; MML. maxillo-mandibular ligament; SH, sterno-hyoideus muscle.

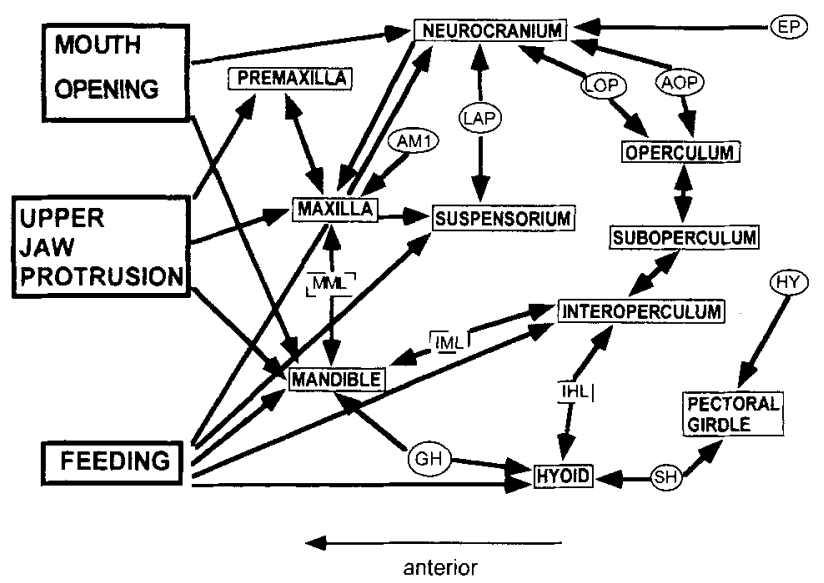

Fig. 13. Complex structural network in the head of teleosts related to mouth opening, upper jaw protrusion, and feeding. Solid rectangles: bony elements; parallelograms: muscles; interrupted rectangles: ligaments. Modificd from Lauder (1982).

AM1. first division of the adductor mandibulae muscles; AOP. adductor operculi muscle; EP, epaxial muscles; GH, genio-hyoideus muscle; HY, hypaxial (obliquus inferioris) musculature: IHL, interoperculo-mandibular ligament; IML, interoperculo-mandibular ligament; $\mathbf{L A P}$, levator arcus palatini muscle: LOP. levator operculi muscle; MML, maxillo-mandibular ligament: SH. stcrno-hyoideus muscle. 


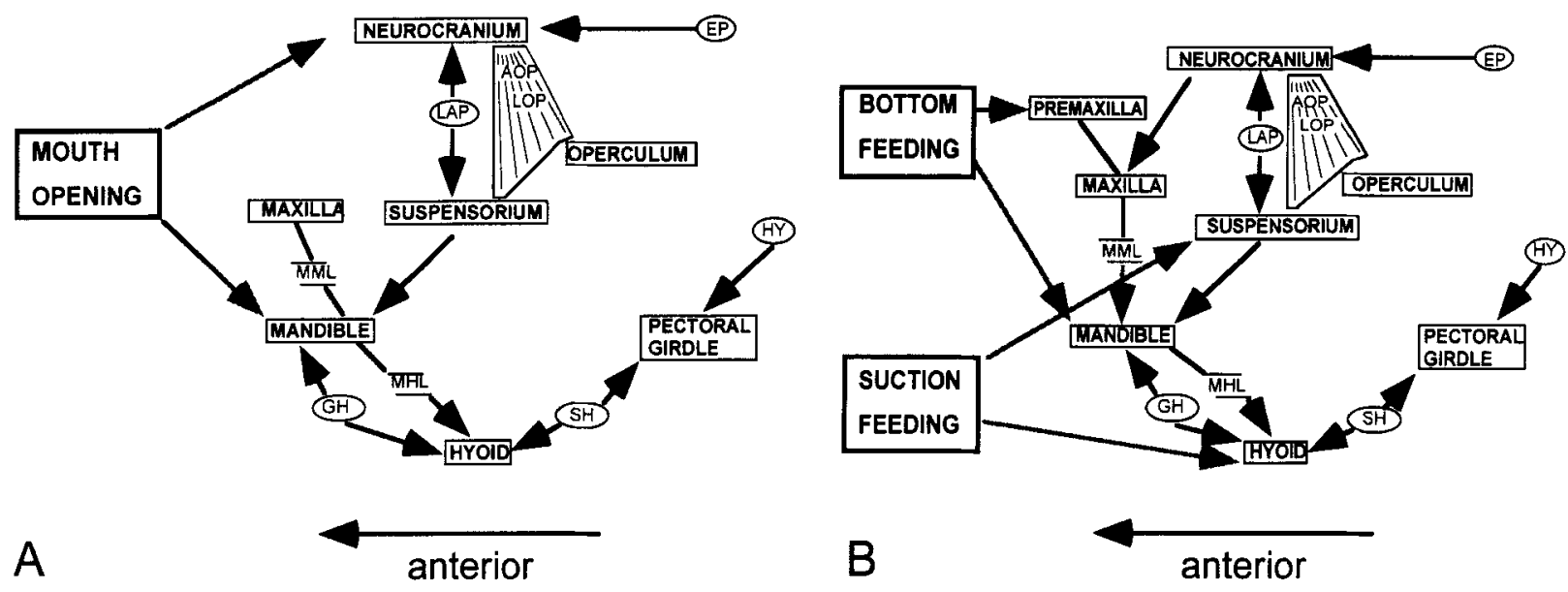

Fig. 14. Structural network in the head of pycnodonts. A. During mouth opening. B. During bottom and suction feeding. Solid rectangles: bony elements; parallelograms: muscles; interrupted rectangles: ligaments.

AOP, adductor operculi muscle; EP, epaxial muscles; GH, equivalent to genio-hyoideus muscle of teleosts; HY, hypaxial (obliquus inferioris) musculature; LAP, levator arcus palatini muscle; LOP, levator operculi muscle; MHL, mandibulo-hyoid ligament; MML, maxillo-mandibular ligament; SH, equivalent to sterno-hyoideus muscle of teleosts.

rocranium with the suspensory apparatus and supports the mandibular depression by levation of the suspensorium (Figs 12, 13, 14: LAP). The $\mathrm{m}$. adductor arcus palatini lies medial to the $\mathrm{m}$. levator arcus palatini. The action of the adductor arcus palatini muscles was probably that to draw the hyomandibula and the pterygoid arch inward and forward. It is hypothesised herein, that the suspensorial abduction is caused mainly by the $m$. levator arcus palatini and probably the the levator portion of the operculum muscles, whereas the hyoid apparatus apparently did not take part in the abduction of the suspensory apparatus.

It is also proposed herein, that the levator and dilatator operculi muscles, two structural specialisations, which are found in halecostomes, have been shifted mostly from the opercular apparatus to the suspensorium, because of reduction of the operculum (Fig. 14, LOP, AOP). The levator is thus not a distinct muscle. In addition, the interopercular bone with the interopercular ligament, which are important structures in teleosts for mouth opening, are absent in pycnodonts.

There are other possible structural innovations, which are related to control of water flow and suction feeding in teleosts (Fig. 13). In contrast to primitive actinopterygians, where the maxilla forms the lateral wall of the adductor chamber, the maxilla becomes free from the cheeks and pivots on a medially directed process posterior to the vomer. The maxilla swings extremely forward during mouth opening. The force, that results from the mandibular depression is transferred to the maxilla via the maxillo-mandibular ligament, and the distal portion of the maxilla is moved anteriorly. Angular-maxillary swing is initiated by neurocranial elevation (epaxial neurocranial coupling). In pycnodonts, the maxilla is free and movable in more advanced pycnodonts with the exception of $\dagger$ Arduafrons and $\dagger$ Mesturus and probably also of $\dagger$ Hadrodus and $\dagger$ Micropycnodon. The maxilla is generally large and wide, always edentulous and forms the postero-lateral margin of the mouth cleft. It was anchored anteriorly by ligaments and an articular peg, that was situated in a groove posterior to the premaxillary process in most pycnodonts (except in Mesturus and closely allied genera as $\nmid$ Arduafrons). It is hypothesised. that during mandibular abduction the maxilla would swing antero-ventrally caused by the 1 . maxillo-mandibularis on its neurocranial pivot, forming a sidewall to the buccal opening preventing water flow into the oral cavity from the corners of the mouth. Two forces are generally important in maxillary swing. The force resulting from the mandibular depression is transferred to the maxilla via the maxillo-mandibular ligament. so that the distal portion of the maxilla is moved anteriorly. Progressive increase of the 'coronoid' process height reduces the slack in the maxillomandibular ligaments, which are inserted near to or even on it, increasing the efficiency and speed of the jaw movements. In addition, a torquing force is brought to the antero-medial process on the maxilla, when the neurocranium is elevated by the epaxial muscle initiating the forward swing of the maxilla. The maxillary swing results in antero-posteriorly oriented streamlines, which increase the velocity of water flow into the oral cavity. But it also would play against the premax- 
illary process with its antero-medial articulation peg. so that the premaxilla consequently moves slightly forward enlarging the buccopharyngeal cavity. In addition, the medial and anterior portions of the naxillo-mandibular ligament insert on the ventral surface of the premaxilla in many extant actinofterygians. This arrangement was probably also present in pycnodonts. Thus. lowcring of the lower jaw results in pulling the maxilla antero-ven rally, which causes upper jaw protrusion. It can be assumed, that the protrusion of the premaxilla is also supported by the lips in its final stage. enhancing grasping or nipping at prey more effectively. Upper jaw protrusion was a structural novelty in pycnodonts. which was not achieved by halecomorphs. Forward protrusion of the inandible happens simultaneously with protrusion of the premaxilla. The protrusion of the upper je.ws is well marked in extant deepbodied actinopterygians (Alexander 1970).

The vomer fits more or less accurately into the $\mathrm{U}$ - or V-shaped basin. which is formed by the paired prearticulars acting thus as a mortar for the pestle (the vomer), when the mouth closes. The long and vertically oriented symphysis of the prearticulars exhibits tuberosities and grooves suggesting connective tissue between the two halves of the lower jaw. There is no reason to believe, tha there was not at least minor lateral adductive and abductive mandibular action as postulated tiy Thurmond (1971. 1974). Lateral movements of the mandibles may have been very limited but would increase the volume of the orobranchial chamber during mouth opening when the susfensorium and the mandibular articulation are sotated outwards. The inflection of the parasphenoid is also related to jaw function in pycnodonts. It deepens the foundations of the vomer. the relatively fixed element of the "grinding mill". and strengthened the base of the vomer. serving to disperse the forces applied to it during biting. But it also foreshortens the skull including the mandible. since the suspensorium maintains a slight forwardly directed projection. This also decre ases the potential mouth opening. The preopercilum of pycnodonts is large and lateral. but its anterior margin provides a firm line of attachm ent for mandibular adductor muscles. It is hypothesised, that musculi adductores mandibulae $w$ se attached to the strong coronoid process. increasing the strength during mouth closing. The biting force resulting by the action of the adductor mandibulae muscles is considerably ir creased by short jaws and vertical orientation of adductor mandibulae muscles
(Gosline 1965). The orientation of the $\mathrm{m}$. adductor mandibulae also plays an important role in increasing the biting force. The more vertical the orientation of the $\mathrm{m}$. adductor mandibulae, the greater is the resulting biting force. The effectiveness of short jaws and vertical orientation of adductor muscles was demonstrated for extant teleosts such as Anarrhichas and Esox by Dobben (1937: Fig. 15). The relationships between ecomorphologically relevant elements such as jaw length. orientation of adductor muscles, and biting force found in Anarrhichas can be transferred to pycnodonts. The mandible of pycnodonts is rather short with well-developed "coronoid process. This, the almost vertical suspensorium, and the deep and foreshortened skull indicate, that the adductor muscles have been large, and more or less vertically oriented reaching far up the lateral side of the neurocranium. The development of a temporal opening in the side-wall of the dermocranium in some higher pycnodonts is related to an increase of adductor muscle mass and improvement of its action by providing extra space during muscle contraction.

The morphology of the mandible and the dorso-ventrally arranged quadrate-symplectic-mandibular joint with supposed extensive cartilage and connective tissue filling of the articular surfaces and capsules suggest, that mandibular movement had its fulcrum on the symplectic-articular connection (Nursall 1999b). There was

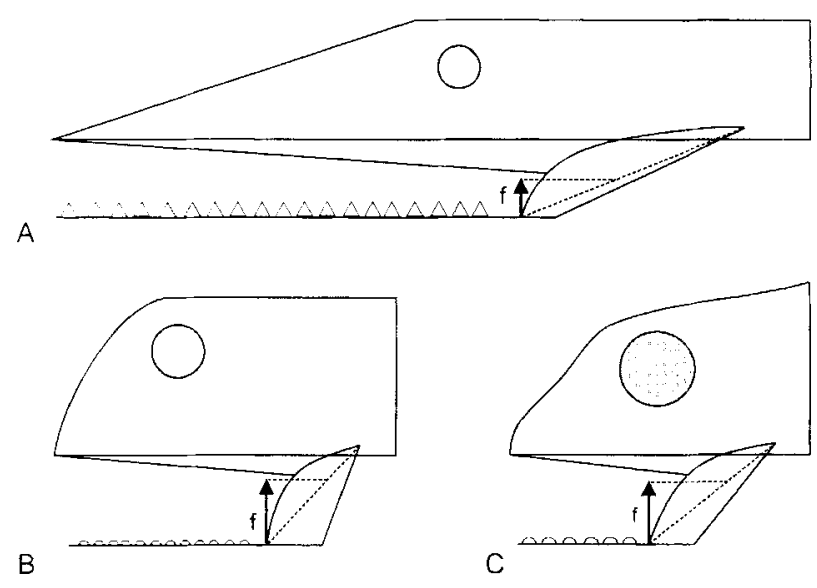

Fig. 15. Schematic models showing the relationships between length of mandible. orientation of adductor muscles (strippled line), angle between mandible and suspensorium, and the resulting biting force (f) as function of these parameters. A. Eson lucius, a ram feeder. B. Anarhichas lupus, a shell crusher. C. Generalised pycnodont. Not to seale. It is evident. that the resulting biting force (f) is greater in actinoptervians with short mandibles, more vertical suspensorium. and deep skull ( $\mathrm{B}$ and $\mathrm{C}$ ) than in predacerous teleosts with long jaw elements (A). 
probably an antero-posterior component of mandibular movement in addition to the simple biting action. Thus, the mandible could slip to and fro enhancing the action of nipping but also gives a shearing moment to chewing during mandibular abduction. However, wear facets found on many prearticular teeth indicate an additional lateral directed shear moment of the jaws during mouth closure.

Spreading of the branchiostegal membrane is caused by the paired branchiostegal rays. The reduction of the plate-like branchiostegal rays to two short ones in pycnodonts may be related to increased mobility of the hyoid arch in the dorso-ventral plane. On the other hand, the reduction indicates a small branchiostegal membrane (see above). This in turn suggests relative small potential for opercular chamber expansion, which would affect the feeding habits. Spreading of the branchiostegal membrane and thus of the orobranchial chamber seems to be less effective than in teleosts. The dorsal branchiostegal elements, from which the interoperculum is supposed to be derived, form a functional linkage between the hyoid arch, operculum, and mandible in halecostomes and played an important role in the early evolution of the levator operculi coupling. I assume, that the linkage was present directly between the branchiostegals and the opercular apparatus without the transmitting interoperculum, because the interoperculum is lacking in pycnodonts.

Expansion of the orobranchial chamber is caused by the depression of the hyoid apparatus, by spreading of the branchiostegal membrane, and upper jaw protrusion. A muscle mass, which extended from the ventral aspect of the paired prearticulars to the ceratohyal and epihyal, was certainly present. The action of the ventral muscles was augmented by drawing the hyoid apparatus ventro-caudally by the sternohyoid muscles.

In summary, pycnodonts were able to enlarge their buccopharyngeal cavity to produce negative pressures during mouth opening. This is caused by the slightly oblique orientation of the suspensorium in pycnodonts, which results in an increase of the volume of the orobranchial cavity, when the hyomandibula is rotated, by upper and lower jaw protrusion, which would also increase the velocity of the water flow directly in front of the mouth, and enlarging of the branchial chamber. Thus, pycnodonts evolved a suction feeding mechanism, which is similar to that of teleosts. This is also supported by the ecomorphology of the skull.
Schaeffer \& Rosen (1961) summarised the evolution of feeding mechanisms in actinopterygians in a widely accepted paper. They recognised at least three major adaptive levels of actinopterygian feeding mechanisms. The pure biting mechanism is interpreted as the most basal form of food acquiring by them, whereas suction feeding is the most advanced one. Contrary, Mallat (1981) stated, that suspension feeding was probably the most primitive method of prey capture in vertebrates, whereas Lauder (1985) and Lauder \& Shaffer 1993 hypothesise, that suction feeding represents primarily the conservative biomechanical pattern found in gnathostomes. Suction feeding is the process of aquatic prey capture, in which the mouth cavity is rapidly expanded to produce a negative pressure inside the buccopharyngeal cavity relative to the surrounding water. This creates an unidirected flow of water into the mouth, when the mouth is opened. Suction feeding of pycnodonts may not have been as efficient as in higher teleosts, since the morphology of the opercular apparatus and the correlated muscles resulting in opercular levation and the transfer of the resulting torque to the mandible via the interoperculum were not developed. Nevertheless, it can also be proposed. that pycnodonts transmitted the forces operating the mandible via the mandibular articulation. since the symplectic bone is tightly sutured to the medial surface of the preoperculum. But suction feeding was probably not the same in pycnodonts. †Mesturus, †Hadrodus, and $\dagger$ Arduafrons, which are interpreted as basal forms (Nursall 1996b, Kriwet 2001) are characterised by comparably large mouth gapes and long maxilla, which were probably more fixed than in advanced forms. It can be assumed, that suction feeding was less effective amongst these pycnodonts.

\section{Digestive system and gut contents}

The digestive system of actinopterygians is divided into pharynx, esophagus, stomach (ventriculus). and intestine. The study of stomach contents is important in order to understand the feeding habits of actinopterygians. Unfortunately, stomach or gastrointestinal contents are rarely preserved in fossil vertebrates. The conservation of fossil digestive remains is correlated to particular taphonomic processes, which are found, e.g., in the sedimentary processes of lithographic limestone deposition in southern Germany and France. 
I hypothesise, that the pharynx of pycnodonts was rather short, because of the foreshortening of the head. The branchial chamber, which was high but also short, is characterised by the presence of branchial teeth in some species (Kriwet 1999b). The uniserial arrangement of branchial teeth in pycncidonts corresponds to the type of Recent omnivise actinopterygians: but they are not homologo ds to the pharyngeal teeth of cichlids or cyprinids (Kriwet 2001). It is assumed. that there is no specialised mastication process nor a horny plate below the occipital region of the head in the dorsal wall of the esophagus supporting the brinchial teeth in pycnodonts based on the morphology of their basioccipital. It can be supposed, that the main role of branchial teeth of pycnodonts was to remove food particles suspended in the water ingested during feeding. In the sane way, indigestible shell fragments were sieved out and probably regurgitated like in many recent durophagous actinopterygians. This also may lead to the consequence. that there are almost no gut contents preserved in pycnodonts. Mastication was mainly effected by the molariform dentition.
Traces of the digestive system have been recognised in some specimens of $\nmid$ Pycnodus platessus (MNHN Bol 126, MNHN Bol 127, MNHN Bol 134. MNHN Bol 135) and in †Gyrodus hexagonut. (VFKO-X 11). The passage of the esophagus into the gut is located rather high in the skull just below the posteriorly extending parasphenoid and notochord. The branchial teeth, when present. are also found in this position. The intestine bends down in a vertical plane and is $\mathrm{U}$ - to $\mathrm{V}$-shaped, making a turning just posterior to the pectoral girdle and running more or less horizontal to the anus in $\nmid$ Pycnodus. Contrary. the intestine of $†$ Gyrodus seems to be longer and more coiled (Fig. 16). I postulate, that the digestive system consisted of a long, rather slender and coiled tube-like structure without any expansion, which may indicate, that pycnodonts did not have any stomach but only an intestine. This observation agrees well with the results found in Recent bottom-feeding teleosts without stomach but well-developed jaw dentitions and/or pharyngeal teeth and feeding specialisations on a single but abundant species. Acid digestion is not present in those fishes and indi-

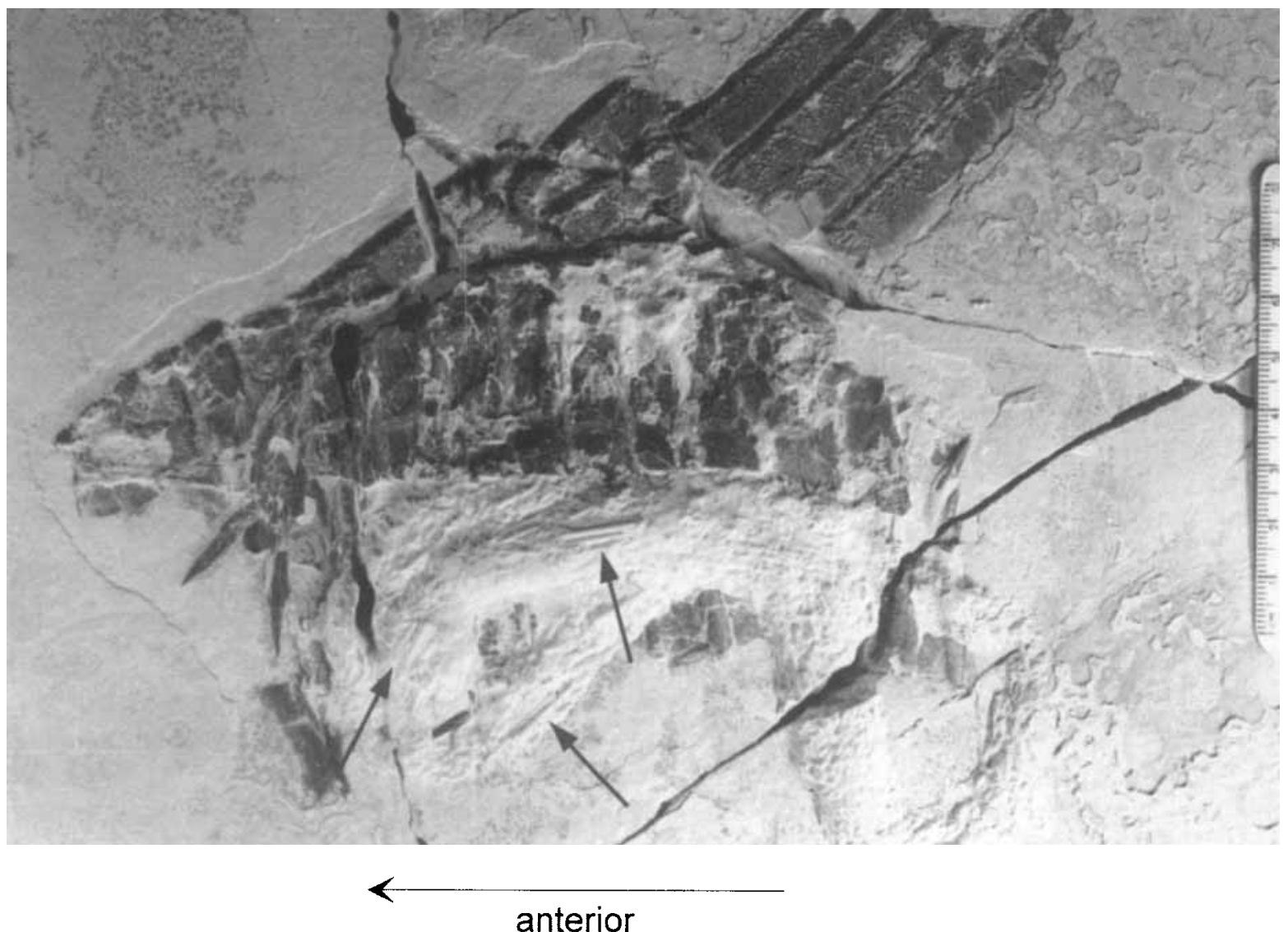

Fig. 16. Remains of the intestine of $\bar{i}$ Grrodus hexagonus (VFKO-X 11) from the upper Kimmeridgian (Upper Jurassic) of Brunn (southern (iermany) as suggested by the presence of monospecific spines of echinoids (arrows). 
Table 1

Gut contents of certain pycnodonts

\begin{tabular}{ll}
\hline Genus & Gut contents \\
\hline $\begin{array}{c}\text { Arduafrons } \\
\text { (a singlc specimen) }\end{array}$ & $\begin{array}{l}\text { spines of monospecific } \\
\text { echinoderms }\end{array}$ \\
† Gyrodus (two specimens) & $\begin{array}{l}\text { spines of monospecific } \\
\text { echinoderms }\end{array}$ \\
$\dagger$ Temanja (a single specimen) & $\begin{array}{l}\text { ? small actinopterygian } \\
\text { vertebrae }\end{array}$ \\
& spines of monospecific \\
$\dagger$ Nursallia (two specimens) & echinoderms \\
& shells of monospecific \\
$\dagger$ Proscinetes & bivalves \\
(a single specimen) & shells of monospecific \\
$\dagger$ Tepexichthys & bivalves \\
(several specimens) & shells of monospecific bivalves \\
$\dagger$ Pycrodus (two specimens) & monospecific snails \\
$\dagger$ Neoproscinetes & (coral fragments?) \\
(a single specimen) &
\end{tabular}

gestible food remains such as shell fragments are rejected.

So far, gut contents of pycnodonts have only be found with certainty in eight genera (Tab. 1). Remarkably, the gut contents are extremely stereotypic. They always consist of monospecific invertebrate remains (Fig. 16). The only exception may be $\uparrow$ Iemanja. Some very small actinopterygian vertebrae are preserved in the coelomic cavity of an acid prepared specimen (AMNH 13963) indicating small actinopterygians as prey. Actually, it is not clear whether the vertebrae are true gut contents or were scattered in the limestone matrix and have been accumulated in the cavity during acid preparation. Monotypy of prey is very characteristic for Recent bottomfeeding actinopterygians, which prefer to feed mainly on a single and locally abundant species. They only change to other prey under unfavourable conditions (e.g., Dugas 1986). A summary of pycnodont gut contents is listed in Table 1 based on personal observations, literature data (Lehman 1966, Blot 1987, Nursall 1999a), and personal communications, e.g., for $\dagger$ Neoproscinetes by I. Rutzky (AMNH, New York). Maisey (1996) indicated small pieces of corals in the abdominal cavity of pycnodonts but without any specific reference ( $\dagger$ Neoproscinetes?).

\section{Conclusions}

This study deals with the feeding mechanisms and the involved elements of the head of fossil pycnodont fishes. Unfortunately, it is not possible, to make direct observations in exclussively fossil forms (e.g., high-speed cinematography and examination of the electrical activity pattern of muscles). Therefore, it is necessary to simplify biological problems into manageable dimensions for practical reasons, especially when fossils are considered. Consequently, the functional morphology of the pycnodont feeding apparatus was deduced from form and structure (anatomy as well as ecomorphology) and in comparison with several extant actinopterygians. It is possible. that the assumptions may not be correct in every detail, since pycnodonts have no extant close relatives to compare with (Kriwet 2001). But in addition to the general assumptions on the mode of living of pycnodonts proposed so far (e.g. Nursall 1996a) the perceptions, especially those of the feeding kinematics, the ecomorphological patterns, and the gut contents made in this study are of special interest for the reconstruction of the ecology of pycnodonts.

It is shown, that the feeding kinematics of pycnodonts are more complex than in halecomorphs and exhibit a transition from the simple stereotypic feeding kinematics that is characteristic for primitive actinopterygians without upper jaw protrusion and less effective enlarging mechanisms of the buccopharyngeal cavity to the modulating feeding kinematics of advanced teleosts including upper jaw protrusion and effective enlargement of the buccopharyngeal cavity. Thus, the pycnodon feeding mechanism may be best addressed as limited modulating feeding $\mathrm{ki}$ nematics involving both basal (bottom feeding) and advanced patterns (suction feeding). Starting of mouth opening is caused by elevation of skull. abduction of suspensorium, and by depression of the hyoid apparatus. Slight expansion of the branchiostegal rays and rotation of the suspensorium increases the orobranchial cavity during continuous suspensorial abduction and hyoid depression. The angular-maxillary swing, protrusion of mandible, and continuous hyoid depression during mouth opening result in an anteriad directed protrusion of the premaxilla. Prey is ingested by nipping and suction (combination of biting and suction feeding). Mouth closing is mainly caused by adduction of mandibular muscles and is supported by hyoid retraction, lowering of neurocranium, suspensorial adduction, and relaxing of involved ligaments.

But feeding kinematics were not completely the same in pycnodonts (Kriwet 1999a). One group, which is mainly composed of $\nmid$ Mesturus, $\dagger$ Arduafrons, and perhaps $\dagger$ Micropycnodon and $\dagger$ Hadrodus, is characterised by long maxilla and premaxilla, which were fixed to the skull without articulations and rather deep mouth clefts. Suc- 
tion feeding $w_{c} s$ obviously less effective. and nipping at benthis prey was not supported by protrusion of upper jaws. I assume. that the adductor muscles were less well-developed in basal pycnodonts with complete dermal covering of the cheeks. anc which lack a temporal opening.

Thus, biting or nipping as well as suction feeding was the mode of food capture in more advanced pycnodonts although it is not possible to reconstruct the total range in respect to the different phases (nipping, biting. inertial suction feeding). The ventrally directed mouth cleft and the horizontal to obliquely arranged ectopterygoid are clear indications. that pycnodonts were benthic forage s with mixed feeding strategies when compared to the condition found in extant coral fishes (e.r... Davis \& Birdsong 1973. Kotrschal \& Thoms on 1989) and cichlids (e.g.. Liem 1979). Pycnodionts as ecomorph may be best grouped within the omnivorous group in contrast to the assumpt ons proposed by Nursall (1996a). It is also hypothesised. that pycnodonts were highly specialised predators on generic or even specific level tased on the few specimens with preserved intestine contents. Specialisation on a single but abu dant prey is a common feature among extant coral fishes. Nevertheless. many of those specialist s have the potential to switch on other prey if they are forced to (e.g.. in capture). After ingestior, shelled prey was crushed with the help of the molariform teeth and well-developed adductor muscles. Abrasion of the occlusal surfaces found in many specimens indicates. that the prey was lot only crushed. but that there was probably also a milling component. There are two possib lities for the absence of intestine contents. (1) It may be related to prey without rigid exoskelet on and which have consequently no fossiliferous potential. (2) The rareness of shell and other prey fragments in the visceral area may be cue to the fact. that most of the hard material was rejected after being crushed. similar to the condition found in many Recent durophagous as tinopterygians (pers. obser.).

The last pycnodonts lived right alongside with the first reef-divelling telcosts with similar ecological demands. which appeared in the Eocene (e.g.. Kriwet 2(001). It seems. that these teleosts were more successful than pycnodonts. Liem (1980) showed that the adaptive sensitivity to changes in the external environment depends on the structure ot the network of interacting constraints in the feeding kinematics. A minor change in the retwork may transfer a static feature into a dy ramic character (e.g.. the simple pathway of jaw protrusion in generalised percoids to the highly modulated pathways in cichlids). Evolutionary patterns may be correlated with differences in the structural network of couplings. Adaptation is not a response of a character to external conditions but it is the response to the totality of the external environment and the evolutionary inventory of an organism, which form together the matrix for evolutionary transformations. The prey specification may have made pycnodonts extremely vulnerable to changes in the environment and to competition by teleosts. It seems, that their evolutionary inventory was depleted and optimising of adaptations in a functional and constructional sense was not possible any more.

\section{Acknowledgements}

This study was part of a project under the supervisorship of H.-P. Schultze and G. Arratia (Berlin). I gratefully acknowledge both for all their help. suggestions, and cncouragement. They also provided many valuable comments on diflerent drafts of the manuscript. Partial financial support was provided by the German Scientific Foundation (DFG, Schu 212/ 13-1). I would like to thank the following persons and institutions for permisson to study material under their care: G. Arratia (Museum für Naturkunde, Berlin), A. Aspes (Museo Civico di Storia Naturale. Verona. Italy), R. Böttcher (Staatliches Museum für Naturkunde. Stuttgart), A. Broschinski (Niedersachsisches Landesmuseum Hannover), S. Calzada (Musco Geológico Del Seminario, Barcelona, Spain), J. A. Cooper (Booth Muscum, Brighton, U.K.), P. Forey and A. Longbottom (The Natural History Museum, London, U.K.), C. Heunisch (Bundesanstalt für Geowissenschaften und Rohstoffe. Hannover). M. Gayet (UMR 5565 CNRS - UFR des Sciences de la Terre. Université Claude Bernard Lyon 1, Lyon. France). J. Gònez-Alba Ruiz (Museo de Geológia, Barcelona. Spain). L. Grande (Department of Geology, Field Muscum of Natural History, Chicago, U.S.A.), H. Jahnke (Institut und Museum für Gcologie und Paläontologie, Göttingen). B. Krebs (Paläontologisches Institut der Freien Universität. Berlin). A. Liebau (Institut und Museum für Geologic und Paläontologie. Tübingen), J. G. Maisey and I. Rutzky (American Museum of Natural History, New York, U.S.A.), A. Müller (Institut für Paläontologie. Universität Leipzig), G. Muscio (Museo Friulano di Storia Naturale, Udine, Italy), A. Paganoni (Museo Civico di Scienze Naturali "E. Caffi", Bergamo. Italy). R. Purdy (Division of Paleontology, United States National Museum. Smithsonian Institution, Washington D.C.. U.S.A.). S. Rodriguez and F. Vigouroux (Muséum d'Histoire naturelle, Iyon, France), M. Röper (Bürgermeister Müller Museum. Solnhofen. Germany), O. Schultz (Naturhistorisches Museum Wien. Austria). M. Tentor and F. Dalla Vecchia (Museo Paleontologico Cittadino-Gruppo Speleologice Monfalconense. A.D.F., Monfalcone, Italy), A. Tintor (Istituto di Paleontologia dell'Università degli Studi di Milani. Mailand and Museo della Vicaria S. Lorenzo, Zogno, Italy). G. Vioh (Jura Museum. Naturwissenschaftliche Sammlungen Eichstätt), P. Wellnhofer (Bayerische Staats sammlung für Paläontologie und historische Geologie, München). S. Wenz (Museum national d'Histoire naturelle, Paris. France). K. A. Frickhinger (Planegg) is thanked for information on material housed in private collections. I am also grateful to the following persons for information and 
discussions: A. Averianov (St. Petersburg, Russia), P. Brito (Rio de Janeiro, Brazil), G. R. Case (New Jersey, U.S.A.), A. de la Pcña (Madrid, Spain), B. G. Gardiner (London, U.K.), M. Gayet (Lyon, France), J. G. Maisey (New York, U.S.A.), A. Mudroch (Hannover), J. R. Nursall (Whaletown, Canada), G. V. R. Prasad (Jammu Tawi, India), F. Pfeil (Munich), the late C. Patterson (London, U.K.), F. J. Poyato-Ariza (Madrid, Spain), D. R. Schwimmer (Columbus, U.S.A.), J. D. Stewart (Los Angeles, U.S.A.), D. Thies (Hannover), and S. Wenz (Paris. France). M. Röper provided the specimen for Figure 16. I am decply indebted to J. R. Nursall and A. Tintori for many valuable comments on an earlier draft of the mansucript. My family is thanked for their patience and help during the last few years. Special thanks go to K. Kussius (Berlin) for all her assistance.

\section{References}

Alexander, R. M. 1967a. Functional design in fishes. 160 pp., London (Hutchinson \& Co. Ltd.).

- 1967b. The functions and mechanisms of the protrusible upper jaws of some acanthopterygian fish. - Journal of Zoology 151: $43-64$.

- 1970. Mechanics of the feeding action of various teleost fishes. - Journal of Zoology 162: 145-156.

Allis, E. P. 1897. The cranial muscles and cranial and first spinal nerves in Amia calva. - Journal of Morphology 12: $487-809$.

Arratia, G. 1997. Basal teleosts and teleostean phylogeny. Palaeo Ichthyologica 7: 1-168.

- 1999. The monophyly of Teleostei and stem-group teleosts. Consensus and disagreements. In Arratia, G. \& Schultze, H.-P. (eds). Mesozoic fishes 2 - Systematics and Fossil Record: 265-334, Verlag Dr. Friedrich Pfeil, München.

Arratia, G. \& Cloutier, R. 1996. Reassessment of the morphology of Cheirolepis canadensis (Actinopterygii). In Schultze. H.-P. \& Cloutier, R. (eds). Devonian Fishes and Plants of Miguasha, Quebec: 165-197, Verlag Dr. Friedrich Pfeil, München.

Barel, C. D. N. 1983. Towards a constructional morphology in cichlid fishes (Teleostei: Perciformes). - Netherlands Journal of Zoology 33: 357-424.

Bartram, A. W. H. 1977. The Macrosemiidae, a Mesozoic family of holostean fishes. - Bulletin of the British Museum (Natural History), Geology 29: 137-234.

Bell, G. Jr. 1986. A pycnodont fish from the Upper Cretaceous of Alabama. - Journal of Paleontology 60 (5): $1120-1126$.

Bellwood, D. R. 1994. A phylogentec study of the parrotfishes, family Scaridae (Pisces: Labroidei), with a revision of genera. - Records of the Australian Museum, Supplement 20: $1-86$.

Blot, J. 1987. L'Ordre des Pycnodontiformes. - Studi e richerche sui giacimenti terziari di Bolca, V: 211 pp., Museo Civico di Storia naturale, Verona.

Boucol, A. J. 1981. Principles of benthic marine palaeoecology. - 463 pp., Academic Press, New York.

Bridge, T. W. 1877. The cranial osteology of Amia calva. Journal of Anatomy (London) 11: 605.

Cate, A. S. \& Evans, I. 1994. Taphonomic significance of the biomechanical fragmentation of live molluscan shell material by a bottom-feeding fish (Pogonias cromis) in Texas coastal bays. - Palaios 9: 254-274.

Clements, K. D. \& Bellwood, D. R. 1988. A comparison of the feeding mechanisms of two herbivorous labroid fishes, the temperate Odax pullus and the tropical Scarus rubroviolacelus. - Australian Journal of Marine and Freshwater Research 39: 87-107.

Cowen, R. 1979. Functional morphology. In Fairbridge, R. W. \& Jablonski, D. (eds). The Encyclopedia of Paleontology:
487-492, Dowden, Hutchinson \& Ross. Strousburg. Pennsylvania.

Davis, W. P. \& Birdsong, R. S. 1973. Coral reef fishes which forage in the water column: A review of their morphology, behavior, ecology, and evolutionary implications. Helgoländer Wissenschaftliche Meeresuntersuchungen 24: 292-306.

Dobben, W. H. van 1937. Über den Kiefermechanismus der Knochenfische. - Archives Néderlandaises de Zoologie 2: $1-72$.

Dugas, C. N. 1986. Food habits of black drum, Pogonias (romis, in southeast Louisiana with emphasis on their predattion of the American oyster. Crassostrea virginica. Louisiana Department of Wildilfe and Fisheries, Contributions of the Marine Research Laboratory. Technical Bulletin 40: $32-38$.

Dullemeijer, P. 1974. Concepts and approaches in animal morphology. 263 pp., Van Gorcum \& Comp. B. V., Assen.

Dunkle. D. H. \& Hibbard, C. W. 1946. Some comments upon the structure of a pycnodontid fish from the Upper Cretaceous of Kansas. - The University of Kansas Science Bulletin 31 (1): 161-175.

Gardiner, B. G. 1967. Further notes on the "palaconiscoid" fishes with a classification of the chondrostei. - Bulletin of the British Museum (Natural History). Geology 14 (5): $143-206$

- 1984. The relationships of the 'palaeoniscoid' fishes. a review based on new specimens of Mimia and Movthomasia from the Upper Devonian of Western Australia. - Bulletin of the British Museum (Natural History), Geology 37 (4): $173-428$.

Gayet, M. 1984. Ichthyoceros spinosus nov. gen.. nov. sp.. du Cénomanien inférieur de Hakel (Liban) et ses aftïnités avec le genre Trewavasia (Pisces, Pycnodontiformes. Coccodontidae). - Bulletin du Muséum national d'Histoire naturelle, Séries 4, 6, section C. 3: 287-307.

Gemballa, S. 1995. Vergleichend-anatomische Untersuchungen am Lokomotionsapparat der Actinopterygii. Phylogenetische Rekonstruktion und funktionelle Hypothesen. - 257 pp., Tübingen (Unpublished Dr. thesis, EberhardKarls Universität).

Gillis, G. B. \& Lauder, G. V. 1995. Kinematics of feeding in bluegill sunfish: Is there a general distinction between aquatic capture and transport behaviors? - The Journal of Experimental Biology 198: 709-720.

Gosline, W. A. 1965. Teleostean phylogeny. - Copeia 1965 (2): $186-194$.

Goodrich, E. S. 1930. Studies on the structure and development of Vertebrates. - 837 pp., Macmillan Press. London.

Gottfried, M. D. 1992. Functional morphology of the feeding mechanism in a primitive palaeoniscid-grade actinopterygian fish. In Mark-Kurik. E. (ed.). Fossil Fishes as Living Animals. Academia 1: 151-158; Academy of Sciences of Estonia, Talinn.

Gould, S. J. 1970. Evolutionary paleontology and the science of form. - Earth-Science Reviews 6: 77-119.

Grande, L. \& Bemis, W. E. 1998. A comprehensive phylogenetic study of amiid fishes (Amiidae) based on comparative skeletal anatomy. An empirical search for interconnected patterns of natural history. - Journal of Vertebrate Paleontology 18, Supplement to 3: 1-690.

Grant, R. E. 1972. Methods and conclusions in functional analysis: a reply. - Lethaia 8: $31-33$.

Gutmann, W. F. 1981. Relationships between invertebrate phyla based on functional-mechanical analysis of the hydrostatic skeleton. - American Zoologist 21: 63-81.

Hickman, C. S. 1988. Analysis of form and function in fossils. - American Zoologist 28: 775-793.

Jarvik, E. 1980. Basic structure and evolution of vertebrates. vol. 1. 575 pp., Academic Press, New York.

Jollie, M. 1984. Development of the head and pectoral skeleton of Amia with notes on the scales. - Gegenbaurs morphologisches Jahrbuch 130: 315-351. 
- 1986. A primes of bone names for the understanding of the actinoptery gian head and pectoral girdle skeletons. Canadian Journal of Zoology 64: 365-379.

Kotrschal. K. \& Tiomson. D. A. 1989. From suckers towards pickers and bi ers: Evolutionary patterns in trophic ecomorphology of tropical marine reef fishes. - Fortschritte der Zoologie 35: 564-568.

Kriwet. J. 1999a. Evolutionary trends in the cranial anatomy of pycnodont ishes (Neopterygii. Pycnodontiformes). Journal of Ver ebrate Paleontology 19. Supplement to 3: 57.

- 1999b. Pycnodent fishes (Neopterygii. †Pycnodontiformes) from the upper Barremian (Lower Cretaceous) of Una (Cucnca Provirce. E-Spain) and branchial teeth in pycnodontid fishes. I'z Arratia. G. \& Schultze. H.-P. (eds). Mosozoic Fishes 2 - Sustematics and Fossil Record: 215-238. Verlag Dr. Friedrich Pfeil. München.

- 2001. A com rehensive Study of Pycnodont Fishes (Neoplerygii. Fycnodontilormes). Unpublished DoctoralThesis. 581 pp. Berlin.

Kriwet. J., Poyato-Ariza. J. F. \& Wenz. S. 1999. A revision of the pycnodonti 1 fish Coelodus subdiscus Wenz 1989. from the Early Creticeous of Montsec (Lleida. Spain). - Treballs del Muset de Geologia de Barcelona 8: 33-65.

Lambers. P. H. 19.1. The Upper Jurassic actinopterygian fish Grodus dicha timius Winkler 1862 (Grodus hexagonus [Blainville 181in]) from Solnhofen. Bavaria and anatomy of the genus $G$ rodus Agassiz. - Proceedings Koninklijke Akademie van Wctenschapn $94(4): 489-544$

- 1992. On the Ic hthyofauna of the Solnhofen Lithographic Limestone (Upper Jurassic. Germany). 336 S. Rijksuniversiteit Gronitgen (Profschrift).

Lauder. G. V. 197). Feeding mechanics in primitive teleosts and in the halecomorph fish Amia calia. - Journal of Zoology 187: 5. $\$ 3-578$.

- 1980a. Evoluticn of the feeding mechanism in primitive actinopterygian fishes: A functional anatomical analysis of Polypterus. Lepisosteus. and Amia. - Journal of Morphology 163: $283-317$.

- $1980 \mathrm{~b}$. On the cvolution of the jaw adductor musculature in primitive gni thostome fishes. - Breviora 460: $1-10$.

- 1980c. Hydrody a mics of prey capture by teleost fishes. In Schneck. D. (e1.). Biofluid Mechanics II: 161-181. Plenum Press. New York.

- 1982. Patterns if evolution in the feeding mechanism of actinopterygian fishes. - American Zoologist 22: $275-285$.

- 1983. Food capture. In Webb. P. W. \& Weihs. D. (eds). Fish Biomechanics: 280-311. Praeger Publishers. New York.

- 1985. Aquatic fieding in lower vertebrates. In Hildebrand. M. Bramble, I'. Liem. K. F. \& Wake. D. B. (eds). Functional Vertebra e Morphology: 210-229. Harvard University Press. Cam ridge.

1990. Functional morphology and svstematics: Studving functional patterns in an historical context. - Annual Revicw of Ecolog" and Systematics 21: 317-340,

- 1991. Biomechinics and evolution: Integrating physical and historical riology in the study of complex systems. In Rayner. J. M. V. \& Wooton. R. J. (eds). Biomechanics and Evolution: 1-19. Cambridge University Press. Cambridge.

- 1995. On the in erence of function from structure. In Thomason. J. J. $\left(e_{1}\right.$ l.). Functional Morphology in Vertebrate Palaeontology: 1-18. Cambridge University Press. Cambridge.

Lauder. G. V. \& Shaffer. H. B. 1993. Design of feeding systems in aquatic vertebrates: Major patterns and their evolutionary interjretations. In Hanken. J. \& Hall. B. K. (eds). The Skull - Volume 3. Functional and Evolutionary Mochanisns: 113-149. The University of Chicago Press. Chicago.

Lehman. J.-P. 1966. Actinopterygii. In Pivetcau. J. (ed.). Traité de Paléontologi s. Part 4: 1-242. Masson et C.. Paris.
Liem. K. F, 1967. Functional morphology in the head of the anabantoid telcost fish Helostoma temmincki. - Journal of Morphology 121: 135-158.

- 1970. Comparative functional anatomy of the Nandidae (Pisces: Telcostei). - Fieldiana (Zoology) 56: 1-166.

- 1978. Modulatory multiplicity in the functional repertoirc of the feeding mechanism in cichlid fishes. I. Piscivores. Journal of Morphology 158: 323-360.

- 1979. Modulatory multiplicity in the functional repertoire of the feeding mechanism of cichlid fishes, as excmplified by the invertebrate pickers of Lake Tanganyika. - Journal of Zoology 189: 93-125.

- 1980. Adaptive significance of intra- and interspecific differences in the feeding repertoires of cichlid fishes. American Zoologist 20: 295-314.

- 1993. Ecomorphology of the teleostean skull. In Hanken, J. \& Hall. B. K. (eds). The Skull. Volume 3. Functional and Evolutionary Mechanisms: 422-452. The University of Chicago Press. Chicago.

Lubosch. W. 1929. Vergleichende Anatomie der Kaumuskulatur der Wirbeltiere in fünf Teilen. II. Die Kaumuskeln der Teleosteer. - Morphologisches Jahrbuch 61 (1/2): $49-220$.

Maiscy. J. G. 1996. Discovering fossil fishes. 223 pp., Nevraumont Publishing Company. New York.

Mallat. J. 1981. The suspension feeding mechanism of the larval lamprey Pteromyzon marinus. - Journal of Zoology 194: $103-142$.

McAllister. D. E. 1968. Evolution of branchiostegals and classification of teleostome fishes. - Bulletin de la Muséum national de Canada 221: XIV + $239 \mathrm{pp}$.

Nursall. J. R. 1996a. Distribution and ecology of pycnodont fishes. In Arratia. G. \& Viohl, G. (eds). Mesozoic Fishes - Systematics and Palcoecology: 115-124, Verlag Dr. Friedrich Pfeil. München.

- 1996b. The phylogeny of pycnodont fishes. In Arratia, G. \& Viohl. G. (eds). Mesozoic Fishes - Systematics and $\mathrm{Pa}$ leoecology: 125-152. Verlag Dr. Friedrich Pfeil, München.

- 1999a. The family Mesturidae and the skull of pycnodont fishes. In Arratia. G. \& Schultze, H.-P. (eds). Mesozoic Fishes 2 - Systematics and Fossil Record: 153-188, Verlag Dr. Friedrich Pfeil, München.

- 1999b. The pycnodontiform bauplan: The morphology of a successful taxon. In Arratia. G. \& Schultze, H.-P. (eds) Mesozoic Fishes 2 - Systematics and Fossil Record 189-214. Verlag Dr. Friedrich Pfeil, München.

Nursall. J. R. \& Maisey, J. G. 1991. Neoproscinetes Figueiredo and Silva Santos, 1987. In Maisey, J. G. (ed.). Santana Fossils: 125-136. T.F.H. Publications Inc., New York.

Olsen. P. E. 1984. The skull and pectoral girdle of the parasemionotid fish Watsonulus elugnathoides from the Early Triassic Sakamena group of Madagascar, with comments on the relationships of the Holostean fishes. - Journal of Vertebrate Palcontology 4 (3): 481-499.

Osse. J. W. M. 1969. Functional morphology of the head of the perch (Perca fluviatilis L.): An electromyographic study. - Netherlands Journal of Zoology 19 (3): 289-392.

Osse. J. W. M. \& Muller. M. 1980. A model of suction feeding in teleostean fishes with some implications for ventilation. In Ali. M. A. (ed.). Environmental Physiology of Fishes: 335-351. Plenum Press, New York.

Patterson. C. 1973. Interrelationships of holosteans. In Greenwood, P. H., Miles, R. S. \& Patterson, C. (eds). Interrelationships of Fishes: 233-302, Academic Press, London.

Patterson. C. 1977. The contribution of paleontology to teleostean phylogeny. In Hecht, M. K., Goody, P. C. \& Hecht. B. M. (eds). Major Patterns in Vertebrate Evolution: 579-643. Plenum Press, New York.

Patterson. C. \& Rosen. D. E. 1977. Review of ichthyodectiform and other Mesozoic teleost fishes and the theory and practice of classifying fossils. - Bulletin of the American Museum of Natural History 158 (2): 83-172. 
Poyato-Ariza, F. J. Talbot. M. R., Fregenal-Martínez, M. A. Meléndez, N. \& Wenz, S. 1998. First isotopic and multidisciplinary evidence for nonmarine coelacanths and pycnodontiform fishes: palaeoenvironmental implications. - Palaeogeography, Palaeoclimatology, Palaeoecology 144: $65-84$.

Raupp, D. M. \& Stanley, S. M. 1971. Principles of Paleontology. 481 pp., W. H. Freeman and Co., San Francisco.

Robba, E. \& Ostrinelli, F. 1975. Studi paleoecologici sul Pliocene ligure. 1. Testimonianze di predazione sui Molluschi pliocenici di Albenga. - Rivista Italiana di Paleontologia e Stratigrafia, 81 (3): 309-372.

Rudwick, M. J. S. 1964. The inference of function from structure in fossils. - British Journal of the Philosophy of Science 15: $27-40$.

Schaelfer, B. 1956. Evolution in subholostean fishes. - Evolution 10: 201-212.

Schaeffer, B. \& Rosen, D. E. 1961. Major adaptive levels in the evolution of the actinopterygian feeding mechanism. - American Zoologist 1 (2): 187-204.

Schultze, H.-P. 1993. The head skeleton of fishes. In Hanken, J. \& Hall, B. K. (eds). The Skull - Volume 2: 189-254, The University of Chicago Press, Chicago and London.

Schultze, H.-P. \& Arsenault, M. 1985. The panderichthyid fish Elpistostege: A close relative of tetrapods. - Palaeontology 28 (2): 293-309.

Stanley, S. M. 1970. Relation of shell form to life habits in the Bivalvia. - Memoirs of the Geological Society of America 125: 1-296.

Thomas, R. D. K. 1978. Shell form and the ecological range of living and extinct Arcoidea. - Paleobiology 4: $181-194$.

Thurmond, J. T. 1971. Jaw mechanics and paleoecology of Lower Cretaceous pycnodont fishes from Texas. - The Journal of the Alabama Academy of Science 42 (3): $167-168$

- 1974. Lower vertebrate faunas of the Trinity Division in North-Central Texas. - Geoscience and Man 3: 103-129; Baton Rouge, Louisiana.

Tintori, A. 1995. Biomechanical fragmentation in shell-beds from the Late Triassic of the Lombardian Basin (Northern Italy). Preliminary report. - Rivista Italiana di Paleontologia e Stratigrafia 101 (3): $371-380$.
Trewin, N. H. \& Welsh, W. 1976. Formation and composition of a graded estuarine shell bed. - Palaeogeography, Palaeoclimatology, Palaeoecology 19: 219-230.

Wenz, S. 1989a. Une nouvelle espèce de Coelodus (Pisces. Pycnodontiformes) du Crétacé inférieur du Montsech (Province de Lérida, Espagne): Coelodus subdiscus n. sp. - Géobios 22 (4): 515-520.

- 1989b. Iemanja palma n. g., n. sp., Gyrodontidae nouveau (Pisces, Actinopterygii) du Crétacé inféricur de la Chapada do Araripe (N-E du Brésil). - Compte rendu de l'Académie des Sciences 308, Série 2: 975-980.

Westneat, M. W. 1999. Diversity of mechanical design in fish heads: Biomechanics of feeding in fossil and Recent taxa. - Journal of Vertebrate Paleontology 19. Supplement to 3: 84 .

Willem, V. 1942. Contribution à l'étude des organes respiratoires chez les téléostéens plectognathes. 1. Les balistidés. - Bulletin du Musée royal d'Histoire naturelle de Belgique 18 (35): 1-24.

- 1944. Contribution à l'étude des organes respiratoires chez les téléostéens plectognathes. II. Les Chaetodontiformes. - Bulletin du Musée royal d'Histoire naturelle de Belgique 20 (6): 1-21.

- 1945. Contribution à l'étude des organes respiratoires chez les téléostéens plectognathes. III. Les ostracionidés; IV. Le role de l'interoperculaire dans la manoeuvre respiratoire chez les téléostéens. - Bulletin du Musée royal d'Histoire naturelle de Belgique 21 (23): 1-16.

- 1947. Contribution à l'étude des organes respiratoires chez les téléostéens plectognathes. I. Tétradontes et Diodon. - Bulletin du Musée royal d'Histoire naturelle de Belgique 23 (17): $1-17$.

Winterbottom, R. 1974. A descriptive synonymy of the striated muscles of the Teleostei. - Proceedings of the Academy of Natural Sciences, Philadelphia 125: 225-317.

Witmer, L. M. 1995. The extant phylogenetic bracket and the importance of reconstructing soft tissues in fossils. In Thomason, J. J. (ed.). Functional Morphology in Vertebrate Paleontology: 19--33, Cambridge University Press. Cambridge. 